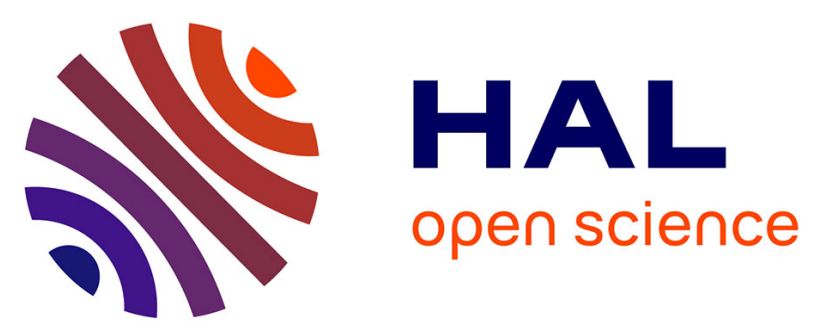

\title{
Evidence for climatic changes around the Matuyama-Brunhes Boundary (MBB) inferred from a multi-proxy palaeoenvironmental study of the GBY\#2 core, Jordan River Valley, Israel
}

Maria Sekar Proborukmi, Brigitte Urban, Steffen Mischke, Henk Mienis, Yoel Melamed, Guillaume Dupont-Nivet, Fred Jourdan, Naama Goren-Inbar

\section{To cite this version:}

Maria Sekar Proborukmi, Brigitte Urban, Steffen Mischke, Henk Mienis, Yoel Melamed, et al.. Evidence for climatic changes around the Matuyama-Brunhes Boundary (MBB) inferred from a multiproxy palaeoenvironmental study of the GBY\#2 core, Jordan River Valley, Israel. Palaeogeography, Palaeoclimatology, Palaeoecology, 2018, 489, pp.166-185. 10.1016/j.palaeo.2017.10.007 . insu01622128

\section{HAL Id: insu-01622128 \\ https://hal-insu.archives-ouvertes.fr/insu-01622128}

Submitted on 24 Oct 2017

HAL is a multi-disciplinary open access archive for the deposit and dissemination of scientific research documents, whether they are published or not. The documents may come from teaching and research institutions in France or abroad, or from public or private research centers.
L'archive ouverte pluridisciplinaire HAL, est destinée au dépôt et à la diffusion de documents scientifiques de niveau recherche, publiés ou non, émanant des établissements d'enseignement et de recherche français ou étrangers, des laboratoires publics ou privés. 


\section{Accepted Manuscript}

Evidence for climatic changes around the Matuyama-Brunhes Boundary (MBB) inferred from a multi-proxy palaeoenvironmental study of the GBY\#2 core, Jordan River Valley, Israel

Maria Sekar Proborukmi, Brigitte Urban, Steffen Mischke, Henk K. Mienis, Yoel Melamed, Guillaume Dupont-Nivet, Fred

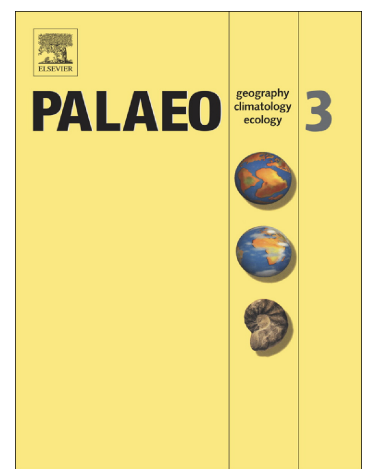
Jourdan, Naama Goren-Inbar

PII:

S0031-0182(17)30661-2

DOI: doi:10.1016/j.palaeo.2017.10.007

Reference: PALAEO 8474

To appear in: Palaeogeography, Palaeoclimatology, Palaeoecology

Received date:

16 June 2017

Revised date:

1 October 2017

Accepted date:

9 October 2017

Please cite this article as: Maria Sekar Proborukmi, Brigitte Urban, Steffen Mischke, Henk K. Mienis, Yoel Melamed, Guillaume Dupont-Nivet, Fred Jourdan, Naama Goren-Inbar , Evidence for climatic changes around the Matuyama-Brunhes Boundary (MBB) inferred from a multi-proxy palaeoenvironmental study of the GBY\#2 core, Jordan River Valley, Israel. The address for the corresponding author was captured as affiliation for all authors. Please check if appropriate. Palaeo(2017), doi:10.1016/j.palaeo.2017.10.007

This is a PDF file of an unedited manuscript that has been accepted for publication. As a service to our customers we are providing this early version of the manuscript. The manuscript will undergo copyediting, typesetting, and review of the resulting proof before it is published in its final form. Please note that during the production process errors may be discovered which could affect the content, and all legal disclaimers that apply to the journal pertain. 
Evidence for climatic changes around the Matuyama-Brunhes Boundary (MBB) inferred from a multi-proxy palaeoenvironmental study of the GBY\#2 core, Jordan River Valley, Israel Maria Sekar Proborukmi ${ }^{\mathrm{a}, *}$, Brigitte Urban ${ }^{\mathrm{a}}$, Steffen Mischke ${ }^{\mathrm{b}}$, Henk K. Mienis ${ }^{\mathrm{c}}$, Yoel Melamed $^{\mathrm{d}}$, Guillaume Dupont-Nivet ${ }^{\mathrm{e}, \mathrm{f}}$, Fred Jourdan $^{\mathrm{g}}$, Naama Goren-Inbar ${ }^{\mathrm{h}}$

${ }^{a}$ Institute of Ecology, Subject Area Landscape Change, Leuphana University Lüneburg, Scharnhorststraße 1, 21335 Lüneburg, Germany. E-mail:

Maria.S.Proborukmi@stud.leuphana.de, b.urban@uni.leuphana.de

${ }^{\mathrm{b}}$ Faculty of Earth Sciences, University of Iceland, Sturlugata 7, Askja, 101 Reykjavik, Iceland. Email: smi@hi.is

${ }^{\mathrm{c}}$ National Natural History Collections, Hebrew University of Jerusalem, Edmond J. Safra Campus, Jerusalem, 9190401, Israel. Email: mienis@ netzer.org.il

${ }^{\mathrm{d}}$ The Mina and Everard Goodman Faculty of Life Sciences, Bar-Ilan University, Ramat-Gan, 5290002, Israel. Email: yomelamed@gmail.com

${ }^{\text {e } U M R-C N R S ~} 6118$ OSUR-Geosciences Rennes, Université de Rennes 1, Campus de Beaulieu Bat. 15, 35042 Rennes Cedex, France. Email: Guillaume.dupont-nivet@ univrennes1.fr

${ }^{\mathrm{f}}$ Institute of Earth and Environmental Sciences, University of Potsdam, Karl Liebknecht Str. 24-25, 14476 Potsdam-Golm, Germany

${ }^{\mathrm{g}}$ Western Australian Argon Isotope Facility, Department of Applied Geology and John de Laeter Centre for Isotope Research, Curtin University, GPO Box U1987, Perth, WA 6845, Australia. Email: F.Jourdan@exchange.curtin.edu.au 
${ }^{\mathrm{h}}$ Institute of Archaeology, Hebrew University of Jerusalem, Mount Scopus, Jerusalem, 9190501, Israel. Email: naama.g@mail.huji.ac.il

*Corresponding author

Abstract

The Acheulian site of Gesher Benot Ya'aqov (GBY) in the Upper Jordan Valley revealed important data on environment and material culture, as well as evidence for hominin behavioural and cognitive patterns documented at the margins of the Hula Palaeo-lake. A 50 m long core (GBY\#2) drilled at the archaeological site has provided a long Pleistocene geological, environmental and climatological record, which expands the existing knowledge of hominin-habitat relationships. Bracketed by two basalt flows dated by ${ }^{40} \mathrm{Ar} /{ }^{39} \mathrm{Ar}$ and based on the identification of the Matuyama-Brunhes Boundary (MBB) and correlation with the GBY excavation site, the sedimentary sequence provides the climatic history around the MBB. Multi-proxy data including pollen and non-pollen palynomorphs, macro-botanical remains, molluscs and ostracods provide evidence for lake and lake-margin environments during Marine Isotope Stages (MIS) 20 and 19. Semi-moist conditions were followed by a pronounced dry phase during MIS 20, and warm and moist conditions with Quercus-Pistacia woodlands prevailed during MIS 19. In contrast to the reconstructed climate change from relatively dry to moister conditions, the depositional environment developed from an openwater lake during MIS 20 to a lake margin environment in MIS 19. Generally shallower conditions at the core site in MIS 19 resulted from the progradation of the lake shore due to the filling of the basin. Micro-charcoal analysis suggests a likelihood of human-induced fire in some parts of the core, which can be correlated with artefact-containing layers of the GBY excavation site. The Hula Palaeo-lake region provided an ideal niche for hominins and other 
vertebrates during global glacial-interglacial climate fluctuations at the end of the Early Pleistocene.

Keywords:

Hula Basin; Levant; Hominins; Pollen record; Plant macro-remains.

1. Introduction

The Acheulian site of Gesher Benot Ya'aqov (GBY) is located within the Jordan River Valley, through which hominins diffused from Africa to Eurasia (Goren-Inbar and Saragusti, 1996; Goren-Inbar et al., 2000, 2004), at the southern margin of the Lake Hula, which was drained in the 1950s. This site, and particularly its recent excavations, have yielded wellpreserved archaeological evidence of the Acheulian culture such as handaxes, cleavers and flakes of basalt, flint and limestone (Alperson-Afil et al., 2009; Goren-Inbar and Saragusti, 1996; Goren-Inbar and Sharon, 2006; Goren-Inbar et al., 1992, 2000, in press; Sharon et al., 2011), as well as wood artefacts associated with an elephant (Palaeoloxodon antiquus) skull (Goren-Inbar et al., 1994). The lake sediments in this site were dated to MIS 20-18 (GorenInbar et al., 2000, Melamed et al., 2016), including the Matuyama-Brunhes Boundary (MBB) at $780 \mathrm{ka} \mathrm{(Head} \mathrm{and} \mathrm{Gibbard,} \mathrm{2005)} \mathrm{during} \mathrm{MIS} 19$ (Lisiecki and Raymo, 2005). The Acheulian material culture remains of GBY are assigned to the African Large Flake Acheulian Tradition (Sharon, 2007), which is characterised by modification of handaxes and cleavers made on large flakes. The Acheulian lithic assemblages were produced on basalt, limestone and flint, each of the raw materials being selected for the production or utilization of particular pre-planned artefacts. In addition, the stratigraphic/sedimentological analyses of the depositional archive and the multiple archaeological occurrences which appear along it 
clearly demonstrate that the Acheulian material culture, as well as the evidence for controlled fire, did not change along the diachronic sequence. Furthermore, the 15 very rich superpositioned archaeological horizons, with an estimated duration of $50 \mathrm{ka}$, demonstrate similar technology and typology, a continuing tradition which is expressed in the lithic assemblages. The multidisciplinary research of the GBY sedimentary sequence and the diverse archaeological and biological remains embedded in it provides us with a large data set that allows detailed reconstruction of the varied environment and its biological components. The geomorphological reconstruction is that of a narrow embayment located south of a freshwater lake in a sedimentary and volcanic terrain (Belitzky, 2002; Feibel, 2001, 2004). The quality of the water in the drainage basin was dictated by the sedimentary and volcanic rocks that surround the Hula Basin (Spiro et al., 2009, 2011) and generally resemble those of the present day. The existence of lake, lake margin and terrestrial habitats enabled the survival of many organisms which inhabited this region from the Early Pleistocene to the Holocene, with minimal species extinction (Ashkenazi et al., 2005, 2010; Mienis and Ashkenazi, 2011; Mischke et al., 2014a; Rabinovich and Biton, 2011; Rosenfeld et al., 2004; Zohar et al., 2014). These palaeoenvironmental conditions are documented by the presence of aquatic submerge taxa such as ostracods, molluscs, fish, crabs and an array of amphibians (as above and Biton et al., 2013, 2016) and a rich Mediterranean flora (Goren-Inbar et al., 2002a, 2002b) including macro- and micro-botanical remains (Kislev and Melamed, 2011; Van Zeist and Bottema, 2009). It was in this setting that the GBY hominins left the remains of their activities, from which particular behavioural patterns are readable. It has been shown that the hominins were very mobile on the landscape, of which they possessed extensive knowledge expressed in the selection pattern of the different raw materials and their transportation into the lake margin sites. Thick basalt slabs were transformed into large cores for the production of bifaces (Goren-Inbar, 2011), thin slabs were used as anvils (Goren-Inbar et al., 2015), small flint pebbles were transformed into an array of retouched tools including evidence for hafting 
(Alperson-Afil and Goren-Inbar, 2016) and limestone pebbles were meticulously selected for use as percussors (Alperson-Afil and Goren-Inbar, 2015). Carcasses of medium-sized and large mammals were processed on the lake margin, leaving various recognizable patterns of bone damage (particular on deer bones) indicating consumption of meat, brain and bone marrow (Rabinovich and Biton, 2011; Rabinovich et al., 2008). Large fish were consumed and their remains were found clustered spatially in several archaeological horizons (Zohar et al., 2014). The presence of the lake also made available a wide variety of food plants; Melamed et al. (2016) identified 9148 plant remains of 55 taxa including nuts, fruits, seeds, vegetables and plants with underground storage organs. Among these, staple plant remains and all-season food plant species were abundantly found in archaeological layers, indicating year-round occupations. Evidence of the use of fire in the processing (roasting) of unpalatable foods, as well as grinding and leaching to remove toxins from food plants, point to the hominins' expertise in dealing with these foods and an adaptation to a Eurasian diet that would have enhanced their survival during the further dispersal into Eurasia (Melamed et al., 2016). Most of these data derived from the rich sites located above the MBB, where although the particular behavioural patterns differ between Acheulian archaeological horizons, the material culture remains are consistently similar to each other in their techno-morphotypological characteristics, pointing to a strong and continuous tradition displaying cognitively advanced hominin abilities (Goren-Inbar et al., in press), during MIS 18. They also show that the GBY hominins were present for a long duration in the Hula Valley and that they knowingly exploited their environment, which provided them with a stable and wide spectrum of subsistence sources. In order to extend our knowledge of the Early-Middle Pleistocene transition (Head and Gibbard, 2005), in 2006 we drilled a core designated GBY\#2 from the GBY archaeological site (Fig. 1) and initiated a study of the sediment of this core.

The research objectives of this study were to analyse the depositional processes and to reconstruct palaeoenvironments during the Early-Middle Pleistocene transition, when 
hominins diffused along the Upper Jordan Valley. The perceived outcomes of this multiproxy study were to enhance the biostratigraphic framework of the area and provide a better understanding of the interaction between climatic changes and environmental conditions during the recorded period.

\section{Regional Setting}

\subsection{Location}

Excavations of the Acheulian site of GBY were located on the eastern bank of the Jordan River, about $4 \mathrm{~km}$ to the south of the recent Lake Hula at ITM E $200417 \mathrm{~m}$ and N $767274 \mathrm{~m}$, on the margin of the Hula Palaeo-lake in northern Israel (Goren-Inbar et al., 2000). The drilling point of the GBY\#2 core was located at the eastern end of the current southern bridge, some 300 m north of the GBY excavation site, at ITM E $259080 \mathrm{~m}$ and N $768450 \mathrm{~m}$ (Fig. 1).

\subsection{Geological Setting}

The GBY site is located at the major transform fault of the Dead Sea Rift that connects the spreading area of the Red Sea to the Zagros-Taurus zone. Along this plate boundary, the Arabian Plate shows a sinistral displacement from the African Plate, which has been active since the Neogene (Belitzky, 2001, 2002). The GBY\#2 core site is situated in the complex Quaternary tectonic setting of the pull-apart Hula Basin (Belitzky, 2002). The Hula Basin belongs to the North Jordan Valley geomorphological unit, which is elevated ca. $70 \mathrm{~m}$ above sea level and intersected by the Jordan River through the deeply incised narrow basaltic canyon downstream of GBY (Horowitz, 1979).

The Benot Ya'akov Formation is exposed along a narrow valley at the Jordan River bank, which extends for about $1 \mathrm{~km}$ to the south and about $1.5 \mathrm{~km}$ to the north of the Benot Ya'aqov 
Bridge (Horowitz, 1973), mainly due to erosion of the Jordan River and recent drainage operations (Goren-Inbar et al., 1992). Palaeomagnetic investigations of the GBY excavation site (Goren-Inbar et al., 2000) and other important archaeological, geological and geochronological studies of the same section (Goren-Inbar et al., 2000, 2002b; Spiro et al., 2009) have demonstrated that this formation was developed at ca. 800-700 ka, during MIS 20-18 (Feibel, 2009 personal communication; Goren-Inbar et al., 2000). These results point to older ages than those indicated by previous studies, which concluded that the Benot Ya'akov Formation is composed of Rissian (ca. MIS 10-6) sediments (Horowitz, 1973, 1975, 1979). Cenozoic volcanic rocks are also common in the local stratigraphy (Horowitz, 1979). The GBY excavation shows that the Benot Ya'akov Formation is composed of fluvio-lacustrine sedimentary rocks showing three dominant lithofacies: beach (coquina, sand and gravel), shallow lacustrine (calcareous mud) and fluvial channel (conglomerate) (Feibel, 2004, 2001; Goren-Inbar et al., in press). The depositional record demonstrates excellent preservation and high diversity of floral remains and faunal fossils in addition to revealing outstanding archaeological remains of the Acheulian culture (Goren-Inbar and Sharon, 2006; Goren-Inbar et al., 1992, 2000, 2002a, 2002b; Van Zeist and Bottema, 2009).

\subsection{Climate and vegetation}

The GBY area is dominated by a Mediterranean climate with cool, wet winters and hot, dry summers and a mean annual temperature of $21^{\circ} \mathrm{C}$ (Van Zeist and Bottema, 2009; Van Zeist et al., 2009). Referring to the vegetation map of the Middle East (Frey and Kürschner, 1989), the potential natural vegetation around the study area is dominated by EuMediterranean vegetation composed mainly of evergreen species. Below $300 \mathrm{~m}$ altitude, a Ceratonio-Pistacion lentisci maquis dominates. At higher altitudes, a Quercion calliprini belt is found up to $1200 \mathrm{~m}$. Open woodland dominated by Quercus ithaburensis originally covered a broad area of northern Israel below $500 \mathrm{~m}$ altitude. Danin (1992) suggests a vegetation map 
of Israel, which shows savannoid Mediterranean vegetation in the vicinity of the GBY\#2 core site. According to Zohary (1982), the alluvial plain is surrounded by semi-steppe chamaephytic and hemicryptophytic shrublands. Although trees are rare in this environment, Pistacia atlantica and Quercus ithaburensis dominate the semi-steppe forests, which usually occur together with or are replaced by the main shrubland communities of Ziziphus lotus or Ziziphus spina-christi.

3. Material and Methods

\subsection{Lithological investigations}

The $50 \mathrm{~m}$ sequence of the GBY\#2 core is composed of sediments about $23 \mathrm{~m}$ thick intercalated between two basalt layers, the underlying basalt between ca. 50.00 and $39.50 \mathrm{~m}$ and the overlying basalt between ca. 16.50 and $1.00 \mathrm{~m}$ (Fig. 2). Based on the detailed lithological observations and descriptions of the core (Spiro and Sharon, unpublished report 2008) (Fig. 2), larger and smaller pieces of basalt are found from $50.00 \mathrm{~m}$ onwards, containing denser and larger vesicles towards $39.50 \mathrm{~m}$ (Fig. 3A). Between about 42.50 and $39.50 \mathrm{~m}$, basalts weathered in various degrees are identified. The overlying sediments between 39.50 and $36.10 \mathrm{~m}$ are composed of calcareous marl with clastic mixtures at the bottom succeeded by dark brown marl showing bioturbation at $36.96 \mathrm{~m}$. At $36.10-32.60 \mathrm{~m}$, there are more sandy sediments which are often rich in well-preserved mollusc shells and shell fragments (Fig. 3B). Marls, calcareous marls and sandy marls with shells and shell fragments alternate.

The sediments between 32.60 and $28.00 \mathrm{~m}$ are mainly composed of dark brown to grey calcareous marl with mixtures of sand and mollusc fragments in thin sandy lenses at about $31.80 \mathrm{~m}$, while a thin peat layer occurs at approximately $28.70 \mathrm{~m}$. Between 28.00 and 25.30 
m, a sequence of calcareous marl, marl, sandy marl with gastropod shells (Fig. 3C) and brown calcareous marl rich in small wood fragments was deposited. This sequence is overlaid by brown marl and a thin peaty layer. Lithology of the subsequent sediments, between 25.30 and $20.15 \mathrm{~m}$, includes layers of peat, dark brown marl and grey sandy marl, which again are overlaid by a massive calcareous marl layer (Fig. 3D) that shows poor preservation of mollusc and is often sterile. Between 20.15 and $16.80 \mathrm{~m}$, sediments are composed of massive calcareous marl with mollusc shells and fragments (Fig. 3E). Core loss occurred between 16.60 and $15.00 \mathrm{~m}$; only loose basalt pieces and calcareous marl with mollusc fragments are found. Loose pieces of weathered basalts compose the lithological sequence at $15.00-8.30 \mathrm{~m}$. From 8.30 to about $3.10 \mathrm{~m}$, coarse basaltic sands are found below a large piece of basalt, which is overlaid by a limonitic crust at about $2.00-1.80 \mathrm{~m}$.

\section{$3.2{ }^{40} \mathrm{Ar} /{ }^{39} \mathrm{Ar}$ dating}

We selected three fresh samples from depths of about 48.30, 45.30 and $14.90 \mathrm{~m}$ for ${ }^{40} \mathrm{Ar} /{ }^{39} \mathrm{Ar}$ dating (Fig. 2) and carefully hand-picked $300 \mathrm{mg}$ of unaltered groundmass chips for each sample. The chips were further leached in diluted HF for one minute and then thoroughly rinsed with distilled water in an ultrasonic cleaner.

Samples were loaded into two large wells of one aluminium disc, $1.9 \mathrm{~cm}$ in diameter and $0.3 \mathrm{~cm}$ deep. These wells were bracketed by small wells that included Fish Canyon sanidine (FCs) used as a neutron fluence monitor for which an age of $28.294 \pm 0.036 \mathrm{Ma}(1 \sigma)$ was adopted (Renne et al., 2011). The discs were Cd-shielded (to minimize undesirable nuclear interference reactions) and irradiated for 2 hours in the Hamilton McMaster University (Canada) nuclear reactor in position 5C. The mean J-values computed from standard grains within the small pits and determined as the average and standard deviation of J-values of the small wells for each irradiation disc are given along with the raw data in Supplementary Table A.1.1-3. Mass discrimination is given in the supplementary table for each sample and was 
monitored using an automated air pipette and calculated relative to an air ratio of $298.56 \pm$ 0.31 (Lee et al., 2006). The correction factors for interfering isotopes were $\left({ }^{39} \mathrm{Ar} /{ }^{37} \mathrm{Ar}\right)_{\mathrm{Ca}}=$ $7.30 \times 10^{-4}( \pm 11 \%),\left({ }^{36} \mathrm{Ar} /{ }^{37} \mathrm{Ar}\right)_{\mathrm{Ca}}=2.82 \times 10^{-4}( \pm 1 \%)$ and $\left({ }^{40} \mathrm{Ar} /{ }^{39} \mathrm{Ar}\right)_{\mathrm{K}}=6.76 \times 10^{-4}( \pm 32 \%)$ for the McMaster reactor and (39Ar/37 Ar) Ca $=7.06 \times 10-4( \pm 7 \%),(36 \mathrm{Ar} / 37 \mathrm{Ar}) \mathrm{Ca}=2.81 \times 10-4$ $( \pm 3 \%)$ and $(40 \mathrm{Ar} / 39 \mathrm{Ar}) \mathrm{K}=6.76 \times 10-4( \pm 10 \%)($ Cosca et al., 2011$)$ for the USGS TRIGA reactor.

The ${ }^{40} \mathrm{Ar} /{ }^{39} \mathrm{Ar}$ analyses were performed at the Western Australian Argon Isotope Facility at Curtin University. The three samples were step-heated in a double vacuum high frequency Pond Engineering@ furnace. The gas was purified in a stainless steel extraction line using two AP10 and one GP50 SAES getters and a liquid nitrogen condensation trap. Ar isotopes were measured in static mode using a MAP 215-50 mass spectrometer (resolution of 400; sensitivity of $4 \times 10^{-14} \mathrm{~mol} / \mathrm{V}$ ) with a Balzers SEV 217 electron multiplier using 9 to 10 cycles of peak-hopping.

The data acquisition was performed with the Argus program written by M.O. McWilliams and run under a LabView environment. The raw data were processed using the ArArCALC software (Koppers, 2002) and the ages have been calculated using the decay constants recommended by Renne et al. (2011). Blanks were monitored every 3 to 4 steps and typical ${ }^{40}$ Ar blanks range from $1 \times 10^{-16}$ to $2 \times 10^{-16} \mathrm{~mol}$. Ar isotopic data corrected for blank, mass discrimination and radioactive decay are given in Supplementary Table A.1.1-3. Individual errors in Supplementary Table A.1.1-3 are given at the $1 \sigma$ level. Our criteria for the determination of plateaus are as follows: they must include at least $70 \%$ of ${ }^{39} \mathrm{Ar}$ and they must be distributed over a minimum of 3 consecutive steps agreeing at the $95 \%$ confidence level and satisfying a probability of fit (P) of at least 0.05 . Plateau ages (Fig. 2, Supp. Fig. B1) are given at the $2 \sigma$ level and are calculated using the mean of all plateau steps, each weighted by the inverse variance of their individual analytical error. Inverse isochrons include the 
maximum number of steps with a probability of fit $\geq 0.05$. S-factors showing the spread along the inverse isochron (Jourdan et al., 2009) and ${ }^{40} \mathrm{Ar} /{ }^{36} \mathrm{Ar}$ intercept values are provided. All sources of uncertainties are included in the calculation.

\subsection{Palaeomagnetism}

A first set of 20 pilot palaeomagnetic samples was taken at targeted stratigraphic intervals of ca.100 cm. This pilot sampling was later complemented by a second set of 10 samples at stratigraphic intervals of ca. $30 \mathrm{~cm}$ upon determining the approximate position of the targeted paleomagnetic reversal following the analysis of the pilot samples (Table 1). The sampling positions were determined at a precision of centimetres with respect to the surface reference level of the GBY\#2 core. For the first set of 20 pilot samples, standard 2.5-cm-diameter cylindrical palaeomagnetic cores were taken from the GBY\#2 core-halves with an electric drill mounted with a diamond-coated bit and cooled with water or air depending on the lithological properties. The second set of samples consisted of cubes carved into soft sediments using non-magnetic blades. The samples were oriented perpendicular to the updown orientation of the GBY\#2 core. Because of the random rotations of the GBY\#2 core segments during drilling, the declination of the samples with respect to North could not be determined.

Palaeomagnetic analyses were performed in the shielded environment of the Rennes University palaeo-archaeomagnetic laboratory. The Natural Remanent Magnetization (NRM) was measured using a 2 G Enterprises DC SQUID cryogenic magnetometer. The NRM was demagnetized stepwise using either the $2 \mathrm{G}$ in-line degausser for Alternating Field (AF) demagnetization or an MMTD shielded oven for thermal demagnetization. Demagnetization paths were interpreted on vector end-point diagrams and stereographic projections to isolate magnetic components and identify the Characteristic Remanent Magnetizations (ChRM)

(Dupont-Nivet et al., 2008) (Fig. 4). 


\subsection{Palynology}

From the sediments of the GBY\#2 core, 41 palynological samples were taken. This sampling was mostly conducted at intervals of 5 to $75 \mathrm{~cm}$. Samples were not collected from the calcareous marl between 32.50 and $29.90 \mathrm{~m}$, the sandy marl between 26.65 and $25.40 \mathrm{~m}$ or the calcareous marl between 25.40 and $20.40 \mathrm{~m}$, due to the expected poor preservation of pollen.

Carbonates were removed from about $7-10 \mathrm{~g}$ sediment per sample with $10 \% \mathrm{HCl}$. The residues were then treated in $\mathrm{KOH}$ and the organic compounds were separated from the inorganic ones by $\mathrm{Na}_{6}\left[\mathrm{H}_{2} \mathrm{~W}_{12} \mathrm{O}_{40}\right]$. The organic remains were subsequently treated with $\mathrm{CH}_{3} \mathrm{COOH}$. Non-palynomorph organic remains were removed by acetolysis using $\mathrm{H}_{2} \mathrm{SO}_{4}$ and $\left[\mathrm{CH}_{3} \mathrm{CO}\right]_{2} \mathrm{O}$ solution. The extracted palynomorphs were stained during this process to ease later microscopic identification (Faegri and Iversen, 1989; Moore et al., 1991). The extracted residues were mounted in glycerine and palynomorphs were identified to the family, genus or species level depending on the pollen type and preservation status, using pollen atlases (Beug, 2004, 2015; Faegri and Iversen, 1989; Moore et al., 1991; Reille, 1995, 1998, 1999) and the reference collections of the Palynology Laboratory of the Institute of Ecology, Leuphana University of Lüneburg.

At least 300 grains of arboreal pollen (AP) were counted per sample and a minimum of 350 grains of total AP and non-arboreal pollen (NAP) were counted from samples that contained very little AP. At least 100 pollen grains were counted from the samples that are particularly poor in pollen. Pollen and spores of Cyperaceae, cryptogams, aquatic taxa and the locally over-represented terrestrial taxa such as cf. Solanum dulcamara, Primula clusianatype and Mentha-type were excluded from the basic sum (the sum of AP and NAP). Pollen percentages were calculated and the pollen diagram was plotted using the TILIA software package (Grimm, 1990). The actual percentages are represented by closed curves in colour 
and the 10 times exaggeration of the actual percentage values is represented by open curves with depth bars, to make the low-values taxa that occur in high frequencies more noticeable. Taxa that occur in very low frequencies and percentages were excluded from the pollen diagram and are presented separately (Table 2). The varia group is composed of unknown, respectively indeterminable NAP. Micro-charcoal particles smaller than $100 \mu \mathrm{m}$ encountered during pollen counting were also counted and represented by an individual semi-log curve for each 24x32 mm slide. A combination of cluster analysis (CONISS) (Grimm, 1987) and conventional interpretation was used to define Local Pollen Assemblage Zones (LPAZ).

The aridity index, the (Artemisia+Amaranthaceae)/Poaceae or $(\mathrm{Ar}+\mathrm{Am}) / \mathrm{P}$ ratio, was calculated after Cour and Duzer (1978) and Fowell et al. (2003), where Artemisia and Amaranthaceae are characteristic of dry steppic environments, whereas Poaceae represents relatively moister conditions of steppe, shrub-steppe and woodlands that are more or less similar to the distribution of vegetation around the study area (Danin, 1992; Van Zeist and Bottema, 1991; Van Zeist et al., 2009). The Amaranthaceae family is composed mainly of the Chenopodiaceae sub-family, which was formerly grouped as a separate family. Grass pollen cannot be further determined except for Cerealia-type pollen, which can be separated by grain size $(>37 \mu \mathrm{m})($ Beug, 2015). At the GBY site, Cerealia-type pollen might have originated from wild cereals and grass species such as Aegilops (Van Zeist and Bottema, 2009), part of the local marsh and understory vegetation of the Quercus ithaburensis-Pistacia terebinthus woodland (Van Zeist and Bottema, 2009).

The $(\mathrm{Ar}+\mathrm{Am}) / \mathrm{P}$ curve and other climate-related signals, such as the AP/NAP ratio, representation of Ephedra fragilis-type pollen and Cedrus curve (Figs. 5 and 6) were used to construct and interpret the palaeoclimatic cycles. Species of Ephedra are found in deserts, semi-deserts, desert steppes or seasonally dry habitats (Ickert-Bond and Renner, 2016). In the GBY\#2 core, only pollen of Ephedra fragilis-type has been found, perhaps deriving from 
Ephedra aphylla, which is currently distributed in the Upper Jordan Valley (Danin, 2003), or from Ephedra foeminea, which is a common species of the Mediterranean maquis. Cedrus indicates higher humidity that is likely related to an increase in precipitation or a cooler Mediterranean climate (Van Zeist and Bottema, 2009). These authors also argue that this taxon was probably a component of the altitudinal montane belt.

\subsection{Plant macro-remains}

Samples for macro-botanical analyses were obtained from the same depths as the pollen samples. A total of 20 small-volume samples $\left(40-107 \mathrm{~cm}^{3}\right)$, from between 38.70 and $16.60 \mathrm{~m}$ at intervals of $20 \mathrm{~cm}$ to $2.2 \mathrm{~m}$, were analysed (Fig. 7). A list of macro-botanical counts is found in Supplementary Table A.2. Quantitative comparison between the percentages of plant macro-remains and the mean pollen percentages (Van Zeist and Bottema, 2009) was conducted mainly to assess local environmental conditions and possible factors that influence the distribution of vegetation. The percentage calculations of the macro-remains were based on the total macro-remains found in the sample excluding indeterminate taxa, Stratiotes intermedius, Azolla cf. filiculoides and Salvinia sp. (Fig. 8), while the mean pollen percentages were calculated based on the percentage sum of each taxon with respect to the total AP, divided by the total number of the analysed samples. For a better comparison with the pollen data, some macro-remain taxa were grouped into the respective family.

\subsection{Molluscs and ostracods}

At the same depths as the pollen samples, 39 samples were taken for mollusc and ostracod analyses based on the sediment types and expected good preservation. Molluscs and ostracods were extracted from the sediments using the detergent soaking method (Snyder and Huber, 1996). About 5-7 g of samples were treated in detergent solution for 24 hours and washed under flowing water using a standard sieve number $270(63 \mu \mathrm{m})$. The retained 
material was dried at $105^{\circ} \mathrm{C}$ for three to five hours. Fossils were picked and preserved in vials. Well-preserved molluscs were identified to species level and recorded as presence-absence data (Fig. 9). In addition, all mollusc shells were counted and mostly identified to genus level due to the poor preservation of some of the counted specimens. The ostracod valves were all counted and identified to species level apart from two specimens of Ilyocypris sp. A list of mollusc and ostracod counts is found in Supplementary Table A.3.

\section{Results}

$4.1{ }^{40} \mathrm{Ar} /{ }^{39} \mathrm{Ar}$ dating

Samples from the underlying basalt, GBYH2-48.30 and GBYH2-45.30, yielded well-defined plateau ages of $1195 \pm 67 \mathrm{ka}(\mathrm{MSWD}=1.19 ; \mathrm{P}=0.30)$ and $1137 \pm 69 \mathrm{ka}(\mathrm{MSWD}=0.47 ; \mathrm{P}$ $=0.90)$ respectively (Fig. 2, Supp. Fig. B1). Inverse isochron plots for those two samples yielded ages of $1024 \pm 183 \mathrm{ka}\left({ }^{40} \mathrm{Ar} /{ }^{36} \mathrm{Ar}=319 \pm 22\right)$ and $1097 \pm 165 \mathrm{ka}\left({ }^{40} \mathrm{Ar} /{ }^{36} \mathrm{Ar}=303 \pm\right.$ 18) indistinguishable from the plateau ages within error and with trapped ${ }^{40} \mathrm{Ar} /{ }^{36} \mathrm{Ar}$ values indistinguishable from the atmospheric composition of $298.6 \pm 0.1$ (Lee et al., 2006) adopted in this study. We interpret the two plateau ages of $1195 \pm 67$ and $1137 \pm 69 \mathrm{ka}$ as indicating the eruption ages of these basalts. A sample from the overlying basalt, GBY14.9, yielded a much younger plateau age of $659 \pm 85 \mathrm{ka}(\mathrm{MSWD}=0.66 ; \mathrm{P}=0.81)($ Fig. 2, Supp. Fig. B1) and an inverse isochron age of $638 \pm 118 \mathrm{ka}\left({ }^{40} \mathrm{Ar} /{ }^{36} \mathrm{Ar}=299.8 \pm 2.4\right)$. We interpret the plateau age of $659 \pm 85 \mathrm{ka}$ as indicating the eruption age of this basalt.

\subsection{Palaeomagnetism}

Pilot samples were stepwise demagnetized in detail with thermal as well as AF treatments in order to determine characteristic demagnetization behaviour and the best demagnetization procedure for each lithological section. Basaltic samples yielded excellent AF 
demagnetization of most of the NRM linearly pointing towards the origin (Fig. 4). All basaltic samples were thus demagnetized by AF treatments using the following 17 steps $(0,5,10,15$, $20,25,30,35,40,45,50,55,60,65,70,80,90 \mathrm{mT})$. For all these samples, after occasional removal of a low coercivity component (LCC) below $15 \mathrm{mT}$, the unblocking spectrum indicates a higher coercivity component (HCC) with a relatively soft magnetic mineralogy such as magnetite typical of basalts.

For detrital sediments, thermal treatment yielded better demagnetization paths than AF and was therefore used for all subsequent analyses. Samples were demagnetized until reaching the origin using thermal treatment with the following steps $(20,100,150,180,210$, $\left.240,270,300,330,360,390,420,480,510,530,550,570^{\circ} \mathrm{C}\right)$. Initial NRM has generally low intensities (Table 1) but demagnetization paths decay in linear fashion towards the origin, usually following two distinct ChRM components (Fig. 4). A low-temperature component (LTC) is typically demagnetized between about 20 and $250^{\circ} \mathrm{C}$. A high-temperature component (HTC) decays between about 250 and $400^{\circ} \mathrm{C}$, sometimes extending up to $550^{\circ} \mathrm{C}$. However, in some samples, the HTC was poorly preserved, sometimes partially overprinted by the overlapping LTC, such that they did not yield reliable directions.

The LCC and LTC are found exclusively with a normal polarity orientation (based on inclination alone because of the absence of orientation on the GBY core), while the higher coercivity and HTC show normal and reverse polarity. This clearly identifies the low coercivity and LTC as a normal overprint and suggests a primary magnetization for the HTC. In a majority of samples, the HTC is well expressed, enabling straightforward isolation of normal or reversed polarity inclinations.

ChRM directions were calculated using least square analysis (Kirschvink, 1980) on a minimum of four consecutive steps of the HTC. Line fits were not anchored to the origin 
except for four demagnetizations. ChRM directions have a Maximum Angular Deviation (MAD) below $25^{\circ}$ for sediments (average of $6.6^{\circ}$ ) and below $2^{\circ}$ for basalts (average of $0.6^{\circ}$ ).

Normal and reversed polarity directions were clearly identified on the HTC with linear decay extending through several temperature steps up to $400-450^{\circ} \mathrm{C}$ (quality- 1 directions, Table 1) for 19 samples. There are three samples with a clear reversed polarity, but the directions are less reliable (quality-2 directions) because of directional scatter and/or LTC overlap on HTC resulting in directions slightly divergent from ideal univectorial decay towards the origin. Unreliable direction (quality-3 directions) is identified in one sample and no interpretable results could be obtained from seven other samples. In these samples, polarity determination is ambiguous due to weak magnetization, scattered direction and a strong normal polarity LTC extending up to $450^{\circ} \mathrm{C}$ partially or fully overprinting the HTC. The resulting set of 23 quality-1 and -2 ChRM directions provides reliable palaeomagnetic polarity throughout the sampled section. The polarity determination relied mainly on the inclination of the remanent magnetization expected at $50^{\circ}$ at this latitude and is in good agreement with the average $39^{\circ}$ inclinations for sediments and $44^{\circ}$ for basalts. The slightly lower values in sediments probably reflect inclination shallowing due to depositional and post-depositional processes such as compaction.

Based on these results, a reversal is clearly indicated between the 17.10 and $16.80 \mathrm{~m}$ level (positioned at $16.95+/-0.15 \mathrm{~m}$ ). This does not correspond to a lithological transition between the basalt and the clastic sediments that might be associated with a hiatus in the record. Instead, the reversal lies within the clastic sediments, suggesting there is no large depositional gap associated with the reversal (Figs. 2 and 10).

\subsection{Palynology}


Based on the cluster analysis combined with conventional interpretation, the pollen diagram of the GBY\#2 sediments, between 39.50 and $17.00 \mathrm{~m}$, is subdivided into five LPAZ, LPAZ GBY\#2-1- GBY\#2-5 (Fig. 5).

LPAZ GBY\#2-1 (39.50-36.10 m) includes ten samples in the bottommost second-order cluster (Fig. 5). AP is composed mainly of Quercus calliprinos-type, Quercus ithaburensistype and Cedrus, which has a first peak (C1) at $37.40 \mathrm{~m}$ (Figs. 6A and 10). CupressaceaeJuniperus-type and Ephedra fragilis-type are well represented. NAP is dominated by Menthatype, Primula clusiana-type and cf. Solanum dulcamara and is further characterised by low amounts of Asteraceae and Apiaceae and Azolla cf. filiculoides massulae, while microspores and microsporangia of Salvinia are extremely abundant. The (Ar+Am)/P ratios and microcharcoal are relatively low in this zone (Fig. 5).

The next second-order cluster of 11 samples $(36.10-28.00 \mathrm{~m})$ is subdivided into two third-order clusters, LPAZ GBY\#2-2 (36.10-32.60 m) and LPAZ GBY\#2-3 (32.60-28.00 m). In LPAZ GBY\#2-2, percentages of AP increase. Salix, Cladium and Cyperaceae indeterminate also increase towards the top of the zone, while Ephedra fragilis-type (Figs. 6C, E and F) decreases. Percentages of Cedrus slightly decrease but still show a small peak (C2) at 34.00 m (Figs. 5 and 10). Grasses are relatively abundant, in contrast to decreasing abundances of aquatic taxa. In this zone, the last peak of Salvinia (PS), both of microspores and microsporangia, occurs at $35.90 \mathrm{~m}$ (Figs. 5, 6B and 10). Amaranthaceae, Artemisia, Asteraceae and Apiaceae are important components of NAP, while amounts of Mentha-type, Primula clusiana-type and cf. Solanum dulcamara are markedly lower. The (Ar+Am)/P ratios are relatively low, between 0.03 and 0.33 . This zone shows the highest amounts of microcharcoal and diatoms (Fig. 5) in the entire profile.

LPAZ GBY\#2-3 (32.60-28.00 m) consists of seven samples and is characterised by relatively low percentages of AP. Percentages of Ephedra fragilis-type are low, while values 
of Poaceae and Cyperaceae are relatively high. High percentages of Amaranthaceae (at 29.90 $\mathrm{m}$ ) and Artemisia (at $28.25 \mathrm{~m}$ ) form the first maximum (AA1, Figs. 5 and 10). Values of the $(\mathrm{Ar}+\mathrm{Am}) / \mathrm{P}$ ratios are relatively high and vary between 0.10 and 1.62. Myriophyllum verticillatum, Myriophyllum spicatum and some Salvinia microspores and microsporangia dominate the aquatic plant spectrum. Amounts of micro-charcoal are lower compared to LPAZ GBY\#2-2 (Fig. 5). Although this zone includes about $2.6 \mathrm{~m}$ interval (32.49-29.90 m) without samples at the base, cluster analysis indicates high similarities of all samples in this zone.

LPAZ GBY\#2-4 (28.00-20.15 m) is composed of five samples in the third second-order cluster, characterised by relatively high percentages of AP. Cedrus values are low, Ephedra fragilis-type reaches up to $2 \%$ and percentages of grasses are relatively high. The aquatic taxa are dominated by Pediastrum simplex at the base, while Typha latifolia-type characterises the top of this zone. The $(\mathrm{Ar}+\mathrm{Am}) / \mathrm{P}$ ratios are relatively high, while micro-charcoal yielded low values (Fig. 5). Both conventional and cluster analyses indicate similarities between every sample in this zone.

LPAZ GBY\#2-5 (20.15-17.10 m) includes seven samples of the fourth second-order cluster, which is characterised by high percentages of AP with occurrences of some Pistacia and Olea (Fig. 5). Percentages of Cyperaceae and Ephedra fragilis-type are very low, while percentages of Poaceae and Cerealia-type are relatively high. Asteraceae, Amaranthaceae and Apiaceae dominate the NAP spectrum, though in low amounts, and Cedrus is absent. Pediastrum simplex and Sparganium-type compose the bulk of the aquatic taxa spectrum. The $(\mathrm{Ar}+\mathrm{Am}) / \mathrm{P}$ ratio and counts of micro-charcoal are very low.

\subsection{Plant macro-remains}


Plant macro-remains are mostly found in sediment layers between 38.70 and $26.20 \mathrm{~m}$ depth (Fig. 7). They are dominated by Azolla cf. filiculoides (Figs. 8A and B), Salvinia cf. natans and Salvinia sp. between 38.70 and $33.20 \mathrm{~m}$ and at $28.80 \mathrm{~m}$. Remains of these two taxa occur together with low numbers of Alismataceae, Cyperaceae (Figs. 8J and K), Foeniculum vulgare, Fumaria macrocarpa (Fig. 8D), Lycopus europaeus, Najas delilei, Polygonum lapatifolium, Potamogeton sp., Ranunculus subgen. Batrachium, Scirpus cf. lacustris (Fig. 8L), Scirpus sp., seeds of Stratiotes intermedius, Trapa natans and Typha sp. between 38.70 and $33.20 \mathrm{~m}$. Between 33.20 and $26.20 \mathrm{~m}$, numbers of macrospores and massulae (respectively microsporangia) of Azolla cf. filiculoides, Salvinia cf. natans (Fig. 8C) and Salvinia sp. are lower, but remains of other taxa including Apiaceae, Asteraceae, Cyperaceae, Gymnospermae indeterminate, Ranunculaceae and aquatic taxa such as Alismataceae and Trapa natans (Fig. 7) are more abundant compared to the sediments between 38.70 and $33.20 \mathrm{~m}$. From $25.40 \mathrm{~m}$ to the top of the sediment sequence, the number of plant macro-remains declines; only a few remains of Ranunculus subgen. Batrachium together with macrospores and microsporangia of Salvinia cf. natans and Salvinia sp. are found (Fig. 7).

Percentages of the mean pollen, non-pollen palynomorphs and plant macro-remains of Cladium, Asteraceae, Cyperaceae, Ranunculaceae, Apiaceae, Salvinia microsporangia and Typha sp. are always more or less proportional (Table 3). Exceptions are Apiaceae and Typha latifolia-type, which have a much higher mean pollen proportion, and Ranunculaceae and Salvinia, which have much lower mean pollen and microspore proportions (Table 3).

Taxa recorded by the macro-remains are in good accordance with the corresponding taxa of the pollen record in the lower part of the sequence. In LPAZ GBY\#2-1, macro-remains of reed-swamp and marsh taxa such as Ranunculus sceleratus, Typha sp. and Cyperaceae are abundant. These are found together with freshwater taxa, mainly Salviniaceae, which reach 
their highest values in LPAZ GBY\#2-2. Reed-swamp and marsh taxa, especially Cyperaceae, begin to expand in LPAZ GBY\#2-3, while these and other macro-remains of wetland and aquatic taxa strongly decrease or even disappear completely in LPAZ GBY\#2-4 and LPAZ GBY\#2-5. The near absence of plant macro-remains in the upper ca. $10 \mathrm{~m}$ of the section contrasts markedly with the abundance of pollen.

\subsection{Molluscs and ostracods}

Almost 5000 mollusc shells and operculi and 41 ostracod valves were recorded from GBY\#2. In LPAZ GBY\#2-1, shells are very rare and ostracod valves are absent. Fragments of Melanopsis costata were recorded at 39.40 and 38.70 m; a shell of Theodoxus jordani was also recorded at $38.70 \mathrm{~m}$. Fragments of Valvata and Radix were found at 37.70 and $36.30 \mathrm{~m}$ respectively; a shell of Valvata saulcyi and an operculum of Bithynia were also found at 36.30 m (Fig. 9). Between 36.10 and 32.60 m (LPAZ GBY\#2-2), shells of Valvata (Valvata saulcyi and possibly poorly preserved specimens of other species) reach high abundances, with a maximum of 957 at $33.20 \mathrm{~m}$. Bithynia operculi and Melanopsis shells (Melanopsis spp. including $M$. costata and M. turriformis) are also very abundant in this part of the core. Shells of Bithynia (including B. phialensis), Gyraulus (including G. piscinarum, G. ehrenbergi and G. costulata) and Theodoxus (including T. jordani and T. michonii) were also recorded relatively frequently. Valves of the two ostracods Candona neglecta and Heterocypris salina were recorded between 34.00 and $33.20 \mathrm{~m}$ (Fig. 9). The sediments between 32.60 and 28.00 m (LPAZ GBY\#2-3) contained only two Bithynia operculi and one shell of Valvata saulcyi and Melanopsis costata respectively, while ostracod valves are absent. Shells of Melanopsis (including M. costata and M. buccinoidea), Valvata (including V. saulcyi), Theodoxus and Gyraulus (including G. piscinarum and G. ehrenbergi), fragments of unionid shells and Bithynia operculi were recorded in the sediments between 28.00 and 20.15 m (LPAZ GBY\#24). Valves of Candona neglecta, C. angulata, Physocypria kraepelini, Ilyocypris sp. and 
Heterocypris salina were also recorded (Fig. 9). The abundance and diversity of mollusc shells are high in the uppermost sediments between 20.15 and $17.10 \mathrm{~m}$ (LPAZ GBY\#2-5) and are comparable to those of LPAZ GBY\#2-2 (Fig. 9); most abundant are shells of Valvata, Melanopsis and Bithynia, and Bithynia operculi. Ostracod valves of Candona neglecta, Physocypria kraepelini, Darwinula stevensoni, Loxoconcha galilea and Ilyocypris sp. were recovered from the uppermost sediments (Fig. 9).

\subsection{Amphibia and micromammals}

An undetermined phalanx of an amphibian as well as a metapodial and a femur of undetermined micromammals were found at 33.20 $\mathrm{m}$ in LPAZ GBY\#2-2.

\section{Discussion}

The GBY\#2 core represents one of the first coring campaigns that were conducted at archaeological sites. This core provided a variety of suitable materials for multi-proxy palaeoenvironmental study and dating, establishing environmental and chronological constraints. The MBB, which is recognised in the GBY excavation sediments, was also found at the top of the GBY\#2 core. Consequently, the MBB can be used as a chronological reference for correlation, relating the older parts of the GBY excavation sequence to the sediments of the GBY\#2 core. The effects of climatic changes on depositional environments and lake-level fluctuations at the GBY\#2 core site and its correlation with the wider area of the GBY excavation and other Eastern Mediterranean records around the MBB have been the main focus.

5.1 Assessment of the pollen and plant macro-remain record of the GBY\#2 core 
The plant macro-remain record of the GBY\#2 core (Fig. 7) shows fewer aquatic taxa in comparison to the GBY excavation (Goren-Inbar et al., 2002a; Melamed et al. 2011, 2016 Tab. S4). This record reveals no evidence of woody plants but shows dominance of Cyperaceae and Typha sp. (Fig. 7). These plants grow at the lake margin or in surrounding marsh and wetlands, from which plant remains are not widely transported. On the other hand, the pollen record (Fig. 5) reflects both the local and the regional vegetation. The local vegetation is represented mainly by aquatic taxa, lake-margin marshland taxa of Cyperaceae and Typha latifolia-type and riverine woody taxa such as Salix, Tamarix and Ulmus. Macroremains of Cyperus are relatively abundant and may have dominated the reed community of the Hula Palaeo-lake, rather than Phragmites, as was the case during the Holocene (Payne and Gophen, 2012). This suggests that the grass pollen derived mainly from the surrounding woodland and steppe environments that were temporarily distributed in the study area, as is also indicated by relatively high abundances of Quercus calliprinos-type and Quercus ithaburensis-type, and occurrence of Artemisia, Ephedra fragilis-type and Amaranthaceae pollen. There are no macro-botanical remains of Cedrus, while the pollen is found mainly in LPAZ GBY\#2-1 and GBY\#2-2, marking long-distance transport by wind (Van Zeist and Bottema, 2009). Presently, Cedrus is native only to Lebanon (Van Zeist and Bottema, 2009) or farther afield in Cyprus and Turkey (Biltekin et al., 2015; Goren-Inbar et al., 2002b). Therefore, taxa that are found in both the pollen and the macro-remain records can predominantly be considered as components of the local vegetation.

Mean pollen percentages and the plant macro-remain percentages of the local taxa such as Cladium, Asteraceae and Cyperaceae show mainly proportional ratios (Table 3). On the other hand, the mean pollen percentages of Apiaceae and Asteraceae are higher compared to the macro-remain percentages (Table 3), demonstrating over-representation. Apiaceae and Asteraceae are insect-pollinated families with low pollen production and poor pollen dispersal. Therefore, their occurrence may indicate relatively abundant occurrences at the 
location, or that their pollen was more resistant than other pollen. In contrast, mean percentages of Ranunculaceae and Salvinia macro-remains show higher values than the mean pollen and spore percentages respectively, suggesting under-representation. Ranunculaceae are insect-pollinated and low pollen producers, while Salvinia is a floating fern whose spores are easily transported by water. It is also possible that Ranunculaceae pollen and Salvinia spores are less resistant to weathering than others. Macro-remains of some taxa such as Lycopus europaeus, Medicago sp., Najas cf. minor, Najas delilei and Trapa natans are found but have left no pollen traces, showing very limited distribution (Table 3). However, other factors such as pollen production, resistance and transport mechanisms should also be taken into account.

\subsection{Micro-charcoal}

Previous studies pointing to low frequencies of heavily burned item that are normally produced by lightning, peat burning and volcanism as well as clustered fire-damaged microartefacts possibly indicating hearths (Alperson-Afil, 2008; Alperson-Afil and Goren-Inbar, 2010; Alperson-Afil et al., 2009; Goren-Inbar et al., 2004) suggest that the occurrence of fire around the GBY site was caused by human activities rather than natural agents. In the GBY\#2 core, relatively high micro-charcoal counts are found in LPAZ GBY\#2-1 and GBY\#2-3. The highest frequency occurs between 35.20 and 34.60 m (LPAZ GBY\#2-2) (Fig. 5), perhaps resulting from hominin activities since the inferred relatively moist conditions would have prevented spontaneous burning and volcanism was no longer affecting the region. This possibility is supported by evidence of processing of unpalatable foods, including roasting, by hominins at the GBY site (Melamed et al., 2016). Furthermore, this layer likely corresponds to Layer III-2 (25.80-25.10 m) of the GBY excavation site, in which stone artefacts were found (Fig. 10) (Goren-Inbar et al., in press). Although only small numbers of artefacts were recovered from the oldest sediments of the GBY excavation, which were deposited below the 
MBB, there are definite artefacts such as small flints. These findings indicate that the Acheulian culture was already present in the GBY site in MIS 20 (Goren-Inbar et al., in press). In LPAZ GBY\#2-4 and GBY\#2-5 the counts of micro-charcoal are relatively low (Fig. 5), pointing to a lower intensity of burning in the study area. Whether the burning in these LPAZs was induced by human (Alperson-Afil, 2008; Alperson-Afil and Goren-Inbar, 2010; Goren-Inbar et al., 1992, 2004) or natural agents remains speculative.

\subsection{Palaeoenvironmental reconstruction of the GBY\#2 core}

Calcareous marl and marls of LPAZ GBY\#2-1 represent typical lacustrine sediments indicative of open-water lake environments (Figs. 5 and 7), an interpretation underlined by the dominance of Azolla cf. filiculoides, Salvinia cf. natans and Salvinia sp. The lithological change from calcareous marl to marl and the subsequent decreased abundance of aquatic taxa (Fig. 5) suggest that the depositional environment changed slightly to shallower conditions from approximately $38.30 \mathrm{~m}$ upwards. Van Zeist and Bottema (2009) suggested that the vegetation of the Upper Jordan Valley did not experience strong changes related to the glacial-interglacial fluctuations of the Early Pleistocene. However, the impacts of climatic changes are specifically marked by fluctuations in the arboreal vegetation record and the spread of steppe-like vegetation. In LPAZ GBY\#2-1, relatively high amounts of Quercus calliprinos-type and grasses, low percentages of Cedrus, Artemisia, Amaranthaceae indeterminate and Ephedra fragilis-type and relatively low aridity indices (Fig. 5) suggest semi-moist conditions with a potential mean annual precipitation between 600 and $800 \mathrm{~mm}$ (Quézel and Médail, 2003; Suc and Popescu, 2005). However, pollen counts of Poaceae and Amaranthaceae of the GBY\#2 may also include taxa of local marshes and drier woodland stands, and the aridity index may vary from place to place in different geographic areas (ElMoslimany, 1990; Herzschuh, 2007). Moreover, the relatively moist conditions of LPAZ GBY\#2-1 were probably related to a decrease in temperature (Van Zeist and Bottema, 2009). 
After its highest stand recorded in LPAZ GBY\#2-1, the lake level dropped, producing an even shallower depositional environment characteristic of a lake-margin or lakeshore-near setting in LPAZ GBY\#2-2, which is concluded for the subsequent sediments of the upper LPAZ GBY\#2-2 (from about $33.50 \mathrm{~m}$ ) from the deposition of sandy material containing abundant diatoms tests, well-preserved mollusc shells of different taxa and very low amounts or even absence of pollen of aquatic taxa (Fig. 5). The occurrence of Cyprinidae remains at $33.20 \mathrm{~m}$ suggests that the lake was relatively shallow, with a maximum depth of $5 \mathrm{~m}$ (Zohar et al., 2014). Additionally, higher percentages of riparian woody taxa (Fig. 5) provide evidence for riparian stands close to the lake margin, as shown by their present-day distribution along many rivers in Israel (Danin, 1992). This interpretation is supported by the occurrence of amphibian, micromammalian and ostracod remains; among ostracods, Candona neglecta is able to tolerate significantly drained environments (Rosenfeld et al., 2004; Wagner, 1957) and Heterocypris salina commonly inhabits temporary oligohaline-mesohaline water bodies (Mischke et al., 2014b; Rosenfeld et al., 2004) (Fig. 9). The occurrence of Heterocypris salina in the GBY record is also indicative of small water bodies such as ponds and swamps with increased evaporative enrichment of dissolved salts situated close to the lake, or slightly brackish springs in the vicinity of the drilling site, which are also observed today (Mienis and Ashkenazi, 2011; Mischke et al., 2014a ; Spiro et al., 2011). Compared to LPAZ GBY\#2-1, slightly higher humidity is indicated in the pollen record of LPAZ GBY\#2-2, while relatively cool conditions seem to have continued throughout this zone (Fig. 5). Cooler conditions than today are possibly also indicated by the presence of Candona neglecta valves (Mischke et al., 2014a) (Fig. 9). Fish skeletal elements of Cyprinidae taxa including Luciobarbus longiceps and Carasobarbus canis, native to the Lake Hula and also indicative of lower water temperatures suitable for their breeding, were found at $33.20 \mathrm{~m}$. Therefore, LPAZ GBY\#2-1 and GBY\#2-2 are characteristic of the semi-moist climatic phase 1 of the GBY\#2 core (Figs. 5 and 10). On the whole, from LPAZ GBY\#2-1 to GBY\#2-2 the depositional environment 
became shallower, which likely corresponds to the transition to the arid climatic phase 2 . In LPAZ GBY\#2-2, the overall diversity of biological remains is relatively high.

The fine-grained sediments of LPAZ GBY\#2-3 are mixed with sand and mollusc fragments at the base of the zone (Fig. 2), indicating that higher-energy depositional conditions at the lake margin persisted to about $31.80 \mathrm{~m}$. The subsequent sediments of massive calcareous marl between 31.80 and $28.00 \mathrm{~m}$ indicate a slightly deeper environment, which is supported by the occurrence of the submerged species Myriophyllum verticillatum and Myriophyllum spicatum. As conditions became progressively drier (climatic phase 2), the development of a slightly deeper depositional environment is probably related to a climatically induced lower sedimentation rate. Overall, sediments of LPAZ GBY\#2-3 contain remains of marsh vegetation (Figs. 5 and 7) pointing to swampy conditions, similar to present-day shallow bays and swamps in the Hula Plain (Dimentman et al., 1992; Zohary and Orshansky, 1947). Progressively warmer environmental conditions characterise the youngest part of LPAZ GBY\#2-3 (Fig. 5).

The deposition of marl and occurrence of several aquatic plant taxa in LPAZ GBY\#2-4 indicate that open-water conditions persisted up to about $25.40 \mathrm{~m}$. The subsequent thin peat layer at about $25.30 \mathrm{~m}$ points to a phase of terrestrialisation, which likely represents a shortterm drop in water level. Thereafter, the sediment type changes to marl and calcareous marl up to 20.15 m (Figs. 2 and 3C), which again likely indicates a slightly deeper lake environment. This interpretation cannot be supported by pollen or plant macrofossil evidence due to the sampling gap. However, remains of Cyprinidae at 23.20, 21.50 and $21.40 \mathrm{~m}$ point to a lake environment less than $5 \mathrm{~m}$ deep (Zohar et al., 2014). Overall assessment of the findings may suggest that the water depth increased in this zone from about $25.30 \mathrm{~m}$, probably corresponding to the transition to the moister climatic phase 3. LPAZ GBY\#2-3 and GBY\#24 have been classified as dry but relatively warm periods and assigned to climatic phase 2 
(Fig. 10). However, for the overall interpretation of LPAZ GBY\#2-4 the sampling gap needs to be considered (Fig. 5).

LPAZ GBY\#2-5 is characterized by calcareous marl (Fig. 3D), which was likely deposited under shallow water conditions with a maximum depth of $5 \mathrm{~m}$, indicated by remains of Cyprinidae (Luciobarbus/Carasobarbus) (Zohar et al., 2014) and abundant molluscs and ostracods. The occurrence of ostracod valves of five taxa in the middle of the zone probably points to a variety of micro-habitats in shallow water conditions, while coquina deposits in the upper part of the zone and the lack of ostracod valves in the uppermost sample probably resulted from the accumulation of shells at or near the beach of the lake. Similar to LPAZ GBY\#2-2 and GBY\#2-4, the shallow depositional environment in LPAZ GBY\#2-5 is probably the result of a higher sedimentation rate. The pollen record of LPAZ GBY\#2-5 shows high percentages of AP (mainly of Quercus ithaburensis-type and Quercus calliprinostype), high values of grasses and very low values of steppic elements and aridity index (Fig. 5), suggesting rather moist environmental conditions. This zone characterises the moist and warm climatic phase 3 with denser forest at the end of the GBY\#2 core section (Fig. 10).

In summary, the depositional environment of the GBY\#2 core record reflects a trend of shallowing, subsequent to the deposition of LPAZ GBY\#2-2, with two phases of slightly deeper depositional conditions at the end of LPAZ GBY\#2-3 and GBY\#2-4. Similar shallowing depositional conditions are also described for the beginning of a second-order sedimentary cycle of the GBY excavation (Van Zeist and Bottema, 2009). Considering the age of the overlying basalt (1137 $\pm 69 \mathrm{ka}$, Figs. 2 and 3A), which probably corresponds to MIS 33, an unconformity can be deduced at the bottom of the sediment sequence of GBY\#2. Consequently, this unconformity occurs somewhere between about MIS 32 and 21.

5.4 Correlation of the palynological and other proxy records of the GBY\#2 core with the GBY excavation site 
The pollen diagram of the GBY excavation site is based on 25 samples (Van Zeist and Bottema, 2009) that are subdivided into pollen zones GBY A, B and C, based mainly on the Cedrus curve. In zone A, two small Cedrus peaks mark an increase in humidity, whereas Cedrus values are low to very low in pollen zone B. A peak in Amaranthaceae and Artemisia in zone A and another maximum in zone B (Fig. 10), as well as coinciding minima of Poaceae, are indicative of increased dryness (Van Zeist and Bottema, 2009). The chronological reference for correlation, the $\mathrm{MBB}$, corresponds to the base of pollen zone $\mathrm{B}$ at a depth of $22.10 \mathrm{~m}$ (Van Zeist and Bottema, 2009), and hence zone A was assigned to MIS 20 and bottom part of zone B to MIS 19. In the GBY\#2 core, the MBB is located at a depth of $16.95+/-0.15 \mathrm{~m}$ (Table 1). Due to the higher resolution of the time-equivalent GBY\#2 pollen spectra indicative of warm and moist interglacial conditions, the boundary between MIS 20 and 19 in the GBY excavation record has been modified (Fig. 10). Pollen zone C, which is assigned to MIS 18, is again characterised by increases in Cedrus and Quercus ithaburensistype pointing to higher humidity.

The entire pollen record of the GBY\#2 core is therefore correlated with pollen zone A (samples 1-7) and samples 8 and 9 of pollen zone B of the excavation record (Van Zeist and Bottema, 2009). As the pollen record of the GBY\#2 core has a much higher resolution and represents a thicker sequence compared to the excavation site, palynological correlation is difficult. In zone A of the excavation record, Cedrus shows two different peaks that are correlated with lines $\mathrm{C} 1$ and $\mathrm{C} 2$ in the GBY\#2 pollen diagram (Fig. 10). It has been suggested by Van Zeist and Bottema (2009) that Cedrus may not have been present in the area during phases represented by the older parts of the pollen diagram (zone A). Nevertheless, findings of macro-remains (Goren-Inbar et al., 2002b) and relatively high percentages of Cedrus pollen at the top of the GBY excavation (Layers V-5 and V-6) (Picard, 1965; Van Zeist and Bottema, 2009) suggest that Cedrus occurred around the GBY site during MIS 18 (zone C) or that the pollen was transported by wind from Lebanon (Van Zeist and Bottema, 2009). 
Analysis of the taphonomy of the wood remains suggests that Cedrus pollen was brought into the Benot Ya'aqov embayment (and into the present Jordan River) from western and northwestern areas (Goren-Inbar et al., 2002b).

Between correlation line $\mathrm{C} 2$ and the $\mathrm{MBB}$, only a thin sediment layer in the GBY excavation site $(25.30-22.10 \mathrm{~m})$ can be correlated with the much thicker sequence of the GBY\#2 core (34.00-17.10 m) (Fig. 10). This might suggest that the GBY\#2 drilling point is located closer to the basin depocenter compared to the GBY excavation.

The AA1 (Van Zeist and Bottema, 2009) and findings of lentic molluscs and hygrophilous land snails in most of cycle 1 of the GBY excavation (Mienis and Ashkenazi, 2011), indicating very dry conditions, can be correlated with the GBY\#2 core sequence between about 30.00 and $28.00 \mathrm{~m}$ (Fig. 10). Van Zeist and Bottema (2009) identified a second maximum of Amaranthaceae and Artemisia (AA2), which is not recorded in the GBY\#2 core due to its higher position above the MBB. However, the post-MBB basalt of the GBY\#2 core, dated to ca. $0.66 \mathrm{Ma}$, can be correlated with the exposed basalt flow of the "North of Bridge Acheulian” (NBA) site, about 500 m north of the Benot Ya'aqov Bridge (Sharon et al., 2010). According to these authors, samples of the basalt flow below the Acheulian archaeological horizon were ${ }^{40} \mathrm{Ar} /{ }^{39} \mathrm{Ar}$ dated to $658 \pm 15 \mathrm{ka}$ (mean age), and Acheulian tools similar to those of the GBY excavation were found in this archaeological horizon. Together with the dating results presented here, the NBA can be allocated to the same Acheulian entity as that revealed in the GBY excavation (Sharon et al., 2011).

Looking at the aquatic flora, particularly high percentages of Salvinia occur at the bottom of both pollen diagrams and in the plant macro-remains record of GBY\#2, while this taxon strongly decreases towards the top of the corresponding sediment sections (pollen zone A and GBY\#2-2). The last peak of Salvinia microspores and microsporangia at $35.90 \mathrm{~m}$ in the 
GBY\#2 pollen sequence and sample 5 of the excavation profile (Van Zeist and Bottema, 2009) can therefore be taken as another significant reference point (PS) (Fig. 10).

According to Mienis and Ashkenazi (2011), the PS line in the GBY excavation profile also coincides with the maximum abundance of lentic Basommatophora and hygrophilous land snails including embryonic forms of the Planorbidae family, indicating nutrient-rich conditions of a lacustrine ecosystem. Changes of water depth, water quality and climatic conditions caused a dramatic decrease of these taxa between about $26.50 \mathrm{~m}$ and the MBB. The same authors suggest that the pre-MBB sediments at the GBY excavation site were deposited during cool climatic conditions, referring mainly to the occurrence of the Palaearctic mollusc Carychium minimum and the oxygen isotope analysis of Candona neglecta (Rosenfeld et al., 2004). They also propose that the lake level changed from high levels at the bottom of the sediment sequence $(34.30-31.20 \mathrm{~m})$ to lower levels representing a shallower depositional environment in the subsequent sediment cycle 1 and the beginning of cycle 2 (Fig. 10). This interpretation corresponds to drier and cooler environmental conditions related to climatic phases 1 and 2 of the GBY\#2 core during MIS 20. The study of Mienis and Ashkenazi (2011) also suggests that the post-MBB sediments of the GBY excavation site indicate a short warm phase (between about 18.90 and $16.50 \mathrm{~m}$ ), which may relate to the warm climatic phase 3 of the GBY\#2 core starting shortly before the MBB. The data from the core and the excavation site are not in agreement with regard to the timing of the onset of the warm climatic phase: in the GBY\#2 record this coincided with the transition from MIS 20 to 19, while in the GBY excavation record it occurred later, at the beginning of MIS 19. This discrepancy, however, can be explained by the much higher sampling resolution of the palynological study of the GBY\#2 core, which provides new evidence for a modification of the MIS subdivision of the GBY excavation record.

5.5 Comparison with other Mediterranean palaeoclimatic records 
There are only a few pollen records in the Eastern Mediterranean spanning a time interval comparable to the GBY record, between 900 and $700 \mathrm{ka}$. Joannin et al. (2007) have stated that in the Early and Middle Pleistocene Tsampika section of Rhodes (Greece) between MIS 20 and 17, cold and arid (glacial) climatic conditions are characterised by the herbaceous taxa Artemisia, Asteraceae and Asteroidae, while warmer and moister (interglacial) phases are characterised by taxa such as Quercus, Cedrus and Abies. Langgut (2008) presents similar observations for a south-eastern Mediterranean marine sequence during the last $90 \mathrm{ka}$. The investigation showed that percentages of Artemisia were high during the late Pleistocene cold glacial stages and Quercus pollen (calliprinos-type) showed higher values during the moister and warmer Holocene. Similar features were observed in the GBY\#2 record for the pronounced dry and slightly cooler climatic phase 2 (Fig. 10) within MIS 20, when AP had drastically decreased and NAP were dominated by Artemisia, Asteraceae and Amaranthaceae. Subsequently, Quercus calliprinos-type, Quercus ithaburensis-type, Pistacia and Olea were again characteristic of a relatively warm and moist climate during MIS 19.

Maiorano et al. (2016) have published a multi-proxy record of the Montalbano Jonico section of the Early-Middle Pleistocene transition which reflects interglacial conditions lasting for about $10.6 \mathrm{ka}$ during MIS 19c. MIS 19c was characterized in southern Italy by warm, oligotrophic surface waters with forest expansion, consistent occurrence of woody taxa and moderate abundance of herbaceous ones, suggesting warm and humid conditions prevailing on land. Almogi-Labin (2011) has recalculated the GBY excavation site pollen record of Van Zeist and Bottema (2009) by removing Poaceae and other NAP from the basic sum of pollen following Tzedakis et al. (2006) and plotting the new AP curve against the $\delta^{18} \mathrm{O}$ values of ostracods and the inferred salinity values that are deduced from the ostracod assemblage (Mischke et al., 2010). Although the resolution of the pollen record of Van Zeist 
and Bottema (2009) is very low, Almogi-Labin (2011) stated that during MIS 19, shortly before the MBB, values of AP were relatively low and the lake level was rather low as well.

The pollen record of Tenaghi Philippon (Tzedakis et al., 2006) indicates the occurrence of forests during the temperate phase of MIS 19, with Quercus prevailing among the high AP percentages, and very low percentages of AP during the preceding glacial period of MIS 20, which corresponds to the GBY\#2 record. However, at Tenaghi Philippon, the MBB is located in MIS 20 rather than in MIS 19. This discrepancy, due to the maintenance of remanent magnetisation, has frequently been described for long terrestrial records (Tzedakis et al., 2006; Zhou and Shackleton, 1999). Therefore, an adjustment is required for this deviation. With regard to the GBY\#2 record, the adjustment of the MBB to MIS 19 was established successfully.

In our study of the GBY\#2 records we have amplified and specified the climatic characterisation of MIS 20 and 19 in the Upper Jordan Valley and can show that the climatic conditions shortly before the MBB (773 ka; Channell et al., 2004) during interglacial stage MIS 19 were moist and warm, reflected by a high AP (cycle 2, Fig. 10). Our inferences of a relatively low lake level and lake-margin conditions at the GBY\#2 location are in agreement with the findings of other authors.

\section{Conclusions}

Changes in the depositional environment from open freshwater to shallower lake-margin environments were influenced by an interaction between climatic conditions and variations in sediment supply. Evidence for possible human use of fire is detected in LPAZ GBY\#2-2 near the lakeshore of the Hula Palaeo-lake, which can be correlated with artefact-containing layers of the GBY excavation site. Concerning the deposition of the sediments of LPAZ GBY\#2-2, 
mollusc analysis for the core sediments and the correlating sediments of the GBY excavation sequence indicates abundant freshwater lentic species that, in association with macrophytes, point to a relatively shallow freshwater ecosystem with high nutrient content.

The MBB, which falls within MIS 19, is represented in the GBY excavation as well as in the GBY\#2 record. Post-MBB sediments of MIS 19 and 18 are represented only in the excavation record. Palynological results of the pre-MBB GBY\#2 record indicate at least three climatic phases, based mainly on Cedrus and AP curves, aridity indices and taxa of steppic elements as well as lithological changes. This interpretation is supported by evidence of molluscs, ostracods and fish and their ecological implications. Based on these proxies and the correlation with the established MIS framework of the GBY excavation and the palaeomagnetic investigations, the sediments of the semi-moist climatic phase 1 in the GBY\#2 core correspond to MIS 20d, and the sediments of the cold and dry climatic phase 2 to the glacial period of MIS 20b. The sediments of the younger part of the sequence were deposited shortly before the MBB (phase 3) and imply a pronounced change of the vegetation to Quercus calliprinos-, Quercus ithaburensis- and Pistacia-rich woodlands, representing the warm and moist MIS 19c.

Acknowledgments

The authors thank the Israel Antiquities Authority for financing and supervising the drilling of GBY\#2 and, in particular, Ofer Marder and Chamoudi Khalaily. Gonen Sharon handled the maintenance and storage of the core and participated in its initial description and sampling. Some of the research aspects were conducted thanks to a grant awarded to N.G.-I. by the Israel Science Foundation [Grant No. 300/06] for the Center of Excellence Project entitled 'The Effect of Climate Change on the Environment and Hominins of the Upper 
Jordan Valley between ca. $800 \mathrm{Ka}$ and $700 \mathrm{Ka}$ ago as a Basis for Prediction of Future

Scenarios'. Baruch Spiro was nominated by N.G.-I. to be in charge of describing the core, cutting it into two halves for archiving and sampling. He was also the sole person responsible for sampling and distributing the samples among the multidisciplinary researchers. Thanks go to Mara Goldstein for her study of the malacology, to Irit Zohar for the ichthyological analysis, to Rebecca Biton for the macro-mammal analysis and to Alexandra Sumner for the illustration of the GBY\#2 core. Thanks are due also to the directors of the Institute of Archaeology, Benny Sekay and Smadar Pustilnik, for their continuous support and understanding. Abraham Starinsky of the Institute of Earth Sciences coordinated some of the administrative aspects and we thank him for his academic and psychological support. M.S.P. and B.U. wish to thank the Directorate General of Indonesian Higher Education (Dikti) and the German Academic Exchange Service (DAAD) for the scholarship to support this research, Mario Tucci and Sabine Hansen for their help and discussion concerning laboratory treatments and pollen diagram preparation and Peter Kershaw for his constructive and valuable advice. G.D.-N. acknowledges funding from EU Career Integration Grant 'HIRESDAT’ [Project No. 294282].

\section{Appendices}

Supplementary Table A.1.1. Detailed ${ }^{40} \mathrm{Ar} /{ }^{39} \mathrm{Ar}$ dating results, at $14.90 \mathrm{~m}$, represented in Fig. 2.

Supplementary Table A.1.2. Detailed ${ }^{40} \mathrm{Ar} /{ }^{39} \mathrm{Ar}$ dating results, at $45.30 \mathrm{~m}$, represented in Fig. 2.

Supplementary Table A.1.3. Detailed ${ }^{40} \mathrm{Ar} /{ }^{39} \mathrm{Ar}$ dating results, at $48.30 \mathrm{~m}$, represented in Fig. 2. 
Supplementary Table A.2. Detailed macro-botanical counts represented in Fig. 7.

Supplementary Table A.3. Detailed mollusc and ostracod counts represented in Fig. 9.

Supplementary Figure B.1. Plateau age plots of the underlying basalt (at 48.30 and $45.30 \mathrm{~m}$ ) and overlying basalt (at $14.90 \mathrm{~m}$ ).

\section{References}

Almogi-Labin, A., 2011. The paleoclimate of the Eastern Mediterranean during the transition from early to mid Pleistocene (900 to 700ka) based on marine and non-marine records: An integrated overview. J. Hum. Evol. 60, 428-436. doi:10.1016/j.jhevol.2010.03.007.

Alperson-Afil, N., 2008. Continual fire-making by hominins at Gesher Benot Ya'aqov, Israel. Quat. Sci. Rev. 27, 1733-1739. doi:10.1016/j.quascirev.2008.06.009.

Alperson-Afil, N., Goren-Inbar, N., 2010. The Acheulian Site of Gesher Benot Ya'aqov Volume II: Ancient Flames and Controlled Use of Fire. Springer, New York.

Alperson-Afil, N., Goren-Inbar, N., 2015. Scarce but significant: The limestone component of the Acheulian lithic assemblages of Gesher Benot Ya'aqov, Israel, in: Haidle, M.N., Conard, N., Bolus, M. (Eds.), The Nature of Culture. Vertebrate Paleobiology and Paleoanthropology Vol. X. Springer, New York, pp. 41-56.

Alperson-Afil, N., Goren-Inbar, N., 2016. Acheulian hafting: Proximal modification of small flint flakes at Gesher Benot Ya'aqov, Israel. Quat. Int. 411, 34-43.

Alperson-Afil, N., Sharon, G., Kislev, M., Melamed, Y., Zohar, I., Ashkenazi, S., Rabinovich, R., Biton, R., Werker, E., Hartman, G., Feibel, C., Goren-Inbar, N., 2009. Spatial organization of hominin activities at Gesher Benot Ya'aqov, Israel. Science 326, 1677- 
1680. doi:10.1126/science.1180695.

Ashkenazi, S., Motro, U., Goren-Inbar, N., Biton, R., Rabinovich, R., 2005. New morphometric parameters for assessment of body size in the fossil freshwater crab assemblage from the Acheulian site of Gesher Benot Ya'aqov, Israel. J. Archaeol. Sci. 32, 675-689. doi:10.1016/j.jas.2004.12.003.

Ashkenazi, S., Klass, K., Mienis, H.K., Spiro, B., Abel, R., 2010. Fossil embryos and adult Viviparidae from the Early-Middle Pleistocene of Gesher Benot Ya'aqov, Israel: Ecology, longevity and fecundity. Lethaia 43, 116-127. doi:10.1111/j.15023931.2009.00178.x.

Belitzky, S., 2001. The morphotectonic structure of the lower Jordan Valley - an active segment of the Dead Sea Rift. Stephan Mueller Spec. Publ. Ser. 2, 95-103. doi:10.5194/smsps-2-95-2002.

Belitzky, S., 2002. The structure and morphotectonics of the Gesher Benot Ya'aqov area, Northern Dead Sea Rift, Israel. Quat. Res. 58, 372-380. doi:10.1006/qres.2002.2347.

Beug, H.-J., 2004. Leitfaden der Pollenbestimmung, für Mitteleuropa und angrenzende Gebiete. Verlag Dr. Friedrich Pfeil, München.

Beug, H.-J., 2015. Leitfaden der Pollenbestimmung, für Mitteleuropa und angrenzende Gebiete, second ed. Verlag Dr. Friedrich Pfeil, München.

Biltekin, D., Popescu, S.-M., Suc, J.-P., Quézel, P., Jiménez-Moreno, G., Yavuz, N., Çağatay, M.N., 2015. Anatolia: A long-time plant refuge area documented by pollen records over the last 23 million years. Rev. Palaeobot. Palynol. 215, 1-22.

Biton, R., Geffen, E., Vences, M., Cohen, O., Bailon, S., Rabinovich, R., et al., 2013. The rediscovered Hula painted frog is a living fossil. Nat. Commun. 4, 1959. doi: 
10.1038/ncomms2959.

Biton, R., Boistel, R., Rabinovich, R., Gafny, S., Bailon, S., 2016. Osteological observations on the Alytid Anura Latonia nigriventer with comments on functional morphology, biogeography, and evolutionary history. J. Morphol. 227 (9), 1131-1145.

Channell, J.E.T., Curtis, J.H., Flower, B.P., 2004. The Matuyama-Brunhes boundary interval (500-900 ka) in North Atlantic drift sediments. Geophys. J. Int. 158, 489-505. doi:10.1111/j.1365-246X.2004.02329.x.

Cour, P., Duzer, D., 1978. La signification climatique, édaphique et sédimentologique des rapports entre taxons en analyse pollinique. Ann. Mines Belgique 7-8, 155-164.

Danin, A., 1992. Flora and vegetation of Israel and adjacent areas. Bocconea 18-42.

Danin, A., 2003. Flora of Israel online [WWW Document]. URL http://flora.org.il/en/plants/ (accessed 10.12.16).

Dimentman, C., Bromley, H.J., Por, F.D., 1992. Lake Hula. Reconstruction of the Fauna and Hydrobiology of the Lost Lake. The Israel Academy of Sciences and Humanities, Jerusalem.

Dupont-Nivet, G., Sier, M., Campisano, C.J., Arrowsmith, J.R., DiMaggio, E., Reed, K., Lockwood, C., Franke, C., Hüsing, S., 2008. Magnetostratigraphy of the eastern Hadar Basin (Ledi-Geraru research area, Ethiopia) and implications for hominin paleoenvironments, in: Quade, J., Wynn, J.G. (Eds.), The Geology of Early Humans in the Horn of Africa: Geological Society of America Special Paper 446. The Geological Society of America, Boulder-Colorado, pp. 67-85. doi: 10.1130/2008.2446(03).

El-Moslimany, A.P., 1990. Ecological significance of common nonarboreal pollen: Examples from drylands of the Middle East. Rev. Palaeobot. Palynol. 64, 343-350. 
doi:10.1016/0034-6667(90)90150-H.

Faegri, K., Iversen, J., 1989. Textbook of Pollen Analysis, fourth ed. John Wiley and Sons, New York.

Feibel, C.S., 2001. Archaeological sediments in lake margin environments, in: Stein, J.K., Farrand, W.R. (Eds.), Sediments in Archaeological Context. The University of Utah Press, Salt Lake City, pp. 127-148.

Feibel, C.S., 2004. Quaternary lake margins of the Levant Rift Valley, in: Goren-Inbar, N., Speth, J.D. (Eds.), Human Paleoecology in the Levantine Corridor. Oxbow Books, Oxford, pp. 21-36.

Fowell, S.J.B., Hansen, C.S., Peck, J.A., Khosbayar, P., Ganbold, E., 2003. Mid to late Holocene climate evolution of the Lake Telmen Basin, North Central Mongolia, based on palynological data. Quat. Res. 59, 353-363.

Frey, W., Kürschner, H., 1989. Tübinger Atlas des Vorderen Orients, Karte A VI 1, Vorderer Orient. Vegetation 1:8000000. Dr. Ludwig Reichert Verlag, Wiesbaden.

Goren-Inbar, N., 2011. Culture and cognition in the Acheulian industry - a case study from Gesher Benot Ya'aqov. Phil. Trans. R. Soc. B. 366 (1567), 1038-1049.

Goren-Inbar, N., Belitzky, S., 1989. Structural position of the Pleistocene Gesher Benot Ya'aqov site in the Dead Sea rift zone. Quat. Res. 31, 371-376.

Goren-Inbar, N., Saragusti, I., 1996. An Acheulian biface assemblage from Gesher Benot Ya'aqov, Israel: indications of African affinities. J. F. Archaeol. 23, 15-30. doi:10.2307/530606.

Goren-Inbar, N., Sharon, G., 2006. Invisible handaxes and visible Acheulian biface technology at Gesher Benot Ya'aqov, Israel, in: Goren-Inbar, N., Sharon, G. (Eds.), Axe 
Age: Acheulian Tool-Making from Quarry to Discard. Equinox Publishing Ltd., London, pp. $105-129$.

Goren-Inbar, N., Belitzky, S., Verosub, K.L., Werker, E., Kislev, M.E., Heimann, A., Carmi, I., Rosenfeld, A., 1992. New discoveries at the Middle Pleistocene Acheulian site of Benot Ya'aqov, Israel. Quat. Res. 38, 117-128.

Goren-Inbar, N., Lister, A., Werker, E., Chech, M., 1994. A butchered elephant skull and associated artifacts from the Acheulian site of Gesher Benot Ya'aqov, Israel. Paléorient 20, 99-112. doi:10.3406/paleo.1994.4604.

Goren-Inbar, N., Feibel, C.S., Verosub, K.L., Melamed, Y., Kislev, M.E., Tchernov, E., Saragusti, I., 2000. Pleistocene milestones on the Out-of-Africa Corridor at Gesher Benot Ya'aqov, Israel. Science 289, 944-947. doi:10.1126/science.289.5481.944.

Goren-Inbar, N., Sharon, G., Melamed, Y., Kislev, M., 2002a. Nuts, nut cracking, and pitted stones at Gesher Benot Ya‘aqov, Israel. Proc. Natl. Acad. Sci. U. S. A. 99, 2455-2460. doi:10.1073/pnas.032570499.

Goren-Inbar, N., Werker, E., Feibel, C.S., 2002b. The Acheulian Site of Gesher Benot Ya'aqov, Israel, I The Wood Assemblage. Oxbow Books, Oxford.

Goren-Inbar, N., Alperson, N., Kislev, M.E., Simchoni, O., Melamed, Y., Ben-Nun, A., Werker, E., 2004. Evidence of hominin control of fire at Gesher Benot Ya'aqov, Israel. Science 304, 725-727. doi:10.1126/science.1095443.

Goren-Inbar, N., Alperson-Afil, N., Sharon, G., Herzlinger, G., 2015. A new type of anvil in the Acheulian of Gesher Benot Ya'aqov, Israel. Phil. Trans. T. Soc. B. 370 (1682), 20140353. doi: 10.1098/rstb.2014.0353.

Goren-Inbar, N., Alperson-Afil, N., Sharon, G., Herzlinger, G., in press. The Acheulian Site 
of Gesher Benot Ya'aqov: The Lithic Assemblages. Springer, Dordrecht.

Grimm, E.C., 1987. CONISS: A Fortran 77 program for stratigraphically constrained cluster analysis by the method of incremental sum of squares. Comput. Geosci. 13, 13-35.

Grimm, E.C., 1990. Tilia, Tiliagraph \& Tiliaview. PC spreadsheet and graphics software for pollen data. INQUA Working Group on Data-Handling Methods Newsletter 4, 5-7.

Head, M.J., Gibbard, P.L., 2005. Early-Middle Pleistocene transitions: An overview and recommendation for the defining boundary. Geol. Soc. London, Spec. Publ. 247, 1-18. doi:10.1144/GSL.SP.2005.247.01.01.

Herzschuh, U., 2007. Reliability of pollen ratios for environmental reconstructions on the Tibetan Plateau. J. Biogeogr. 34, 1265-1273. doi:10.1111/j.1365-2699.2006.01680.x.

Horowitz, A., 1973. Development of the Hula Basin, Israel. Isr. J. Earth Sci. 22, 107-139.

Horowitz, A., 1975. The Quaternary stratigraphy and paleogeography of Israel. Paléorient 3, 47-100. doi:10.3406/paleo.1975.4190.

Horowitz, A., 1979. The Quaternary of Israel. Academic Press, New York.

Horowitz, A., 1987. Palynological evidence for the age and rate of sedimentation along the Dead Sea Rift, and structural implications. Tectonophysics 141, 107-115.

Ickert-Bond, S.M., Renner, S.S., 2016. The Gnetales: Recent insights on their morphology, reproductive biology, chromosome numbers, biogeography, and divergence times. J. Syst. Evol. 54, 1-16. doi:10.1111/jse.12190.

Joannin, S., Cornée, J.-J., Moissette, P., Suc, J.-P., Koskeridou, E., Lécuyer, C., Buisine, C., Kouli, K., Ferry, S., 2007. Changes in vegetation and marine environments in the eastern Mediterranean (Rhodes, Greece) during the Early and Middle Pleistocene. J. Geol. Soc. 
London 164, 1119-1131.

Jourdan, F., Renne, P.R., 2007. Age calibration of the Fish Canyon sanidine ${ }^{40} \mathrm{Ar} /{ }^{39} \mathrm{Ar}$ dating standard using primary K-Ar standards. Geochim. Cosmochim. Acta 71, 387-402.

Kirschvink, J.L., 1980. The least-squares line and plane and the analysis of palaeomagnetic data. Geophys. J. Int. 62, 699-718. doi:10.1111/j.1365-246X.1980.tb02601.x.

Kislev, M., Melamed, Y., 2011. The first archaeobotanical record of environmental change and hominin diet in the Out-of-Africa Corridor during the Lower to Upper Paleolithic. Center of Excellence Project No. 858/09.

Koppers, A.A.P., 2002. ArArCALC-software for ${ }^{40} \mathrm{Ar} /{ }^{39} \mathrm{Ar}$ age calculations. Comput. Geosci. $28,605-619$.

Langgut, D., 2008. Late Quaternary palynological sequences from the Eastern Mediterranean Sea. Report GSI/16/08, Geological Survey of Israel.

Lee, J.-Y., Marti, K., Severinghaus, J.P., Kawamura, K., Yoo, H.-S., Lee, J.B., Kim, J.S., 2006. A redetermination of the isotopic abundance of atmospheric Ar. Geochim. Cosmochim. Acta 70, 4507-4512.

Lisiecki, L.E., Raymo, M.E., 2005. A Pliocene-Pleistocene stack of 57 globally distributed benthic d18O records. Paleoceanography 20, PA1003. doi:10.1029/2004PA001071.

Maiorano, P., Bertini, A., Capolongo, D., Eramo, G., Gallicchio, S., Girone, A., Pinto, D., Toti, F., Ventruti, G., Marino, M., 2016. Climate signatures through Marine Isotope Stage 19 in the Montalbano Jonico section (Southern Italy): A land-sea perspective. Palaeogeogr. Palaeoclimatol. Palaeoecol. 461, 341361.doi:10.1016/j.palaeo.2016.08.029.

Melamed, Y., Kislev, M., Weiss,E., Simchoni, O., 2011. Extinction of water plants in the 
Hula Valley: Evidence for climate change. J. Hum. Evol. 60(4), 320-327. doi:10.1016/j.jhevol.2010.07.025.

Melamed, Yoel, Kislev, M.E., Geffen, E., Lev-Yadun, S., Goren-Inbar, N., 2016. The plant component of an Acheulian diet at Gesher Benot Ya'aqov, Israel. Proceedings of the National Academy of Sciences of the USA 113 (51), 14674-14679.

Mienis, H.K., Ashkenazi, S., 2011. Lentic Basommatophora molluscs and hygrophilous land snails as indicators of habitat and climate in the Early-Middle Pleistocene (0.78 Ma) at the site of Gesher Benot Ya'aqov (GBY), Israel. J. Hum. Evol. 60, 328-340. doi:10.1016/j.jhevol.2010.03.009.

Mischke, S., Almogi-Labin, A., Ortal, R., Rosenfeld, A., Schwab, M.J., Boomer, I., 2010. Quantitative reconstruction of lake conductivity in the Quaternary of the Near East (Israel) using ostracods. J. Paleolimnol. 43, 667-688. doi:10.1007/s10933-009-9359-y.

Mischke, S., Ashkenazi, S., Almogi-Labin, A., Goren-Inbar, N., 2014a. Ostracod evidence for the Acheulian environment of the ancient Hula Lake (Levant) during the early-mid Pleistocene transition. Palaeogeogr. Palaeoclimatol. Palaeoecol. 412, 148-159. doi:10.1016/j.palaeo.2014.07.036.

Mischke, S., Almogi-Labin, A., Al-Saqarat, B., Rosenfeld, A., Elyashiv, H., Boomer, I., Stein, M., Lev, L., Ito, E., 2014b. An expanded ostracod-based conductivity transfer function for climate reconstruction in the Levant. Quat. Sci. Rev. 93, 91-105. doi:10.1016/j.quascirev.2014.04.004.

Moore, P.D., Webb, J.A., Collinson, M.E., 1991. Pollen Analysis, second ed. Blackwell Scintific Publications, Oxford.

Payne, R., Gophen, M., 2012. The Hula Peatland: Past, Present and Future (Foreword). Mires 
Peat 9.

Picard, L., 1965. The geological evolution of the Quaternary in the central-northern Jordan Graben. Ametican Geol. Soc. Spec. Pap. 84, 337-366.

Quézel, P., Médail, F., 2003. Ecologie et biogéographie des forêts du bassin méditerranéen Vol. 572. Elsevier, Paris.

Rabinovich, R., Biton, R., 2011. The Early-Middle Pleistocene faunal assemblages of Gesher Benot Ya'aqov: Inter-site variability. J. Hum. Evol. 60, 357-374. doi:10.1016/j.jhevol.2010.12.002.

Rabinovich, R., Gaudzinski, S., Goren-Inbar, N., 2008. Systematic butchering of Fallow deer (Dama) at the early Middle Pleistocene Acheulian site of Gesher Benot Ya'aqov, (Israel). J. Hum. Evol. 54, 134-149.

Reille, M., 1995. Pollen et spores d'Europe et d'Afrique du Nord: Supplément 1. Laboratoire de Botanique Historique et Palynologie, Marseille.

Reille, M., 1998. Pollen et spores d'Europe et d'Afrique du Nord: Supplément 2. Laboratoire de Botanique Historique et Palynologie, Marseille.

Reille, M., 1999. Pollen et spores d'Europe et d'Afrique du Nord: Index. Laboratoire de Botanique Historique et Palynologie, Marseille.

Renne, P.R., Mundil, R., Balco, G., Min, K., Ludwig, K.R., 2010. Joint determination of ${ }^{40}$ K decay constants and ${ }^{40} \mathrm{Ar} * /{ }^{40} \mathrm{~K}$ for the Fish Canyon sanidine standard, and improved accuracy for ${ }^{40} \mathrm{Ar} /{ }^{39} \mathrm{Ar}$ geochronology. Geochim. Cosmochim. Acta 74, 5349-5367.

Renne, P.R., Balco, G., Ludwig, K.R., Mundil, R., Min, K., 2011. Response to the comment by W.H. Schwarz et al. on "Joint determination of K-40 decay constants and Ar-40*/K40 for the Fish Canyon sanidine standard, and improved accuracy for Ar-40/Ar-39 
geochronology" by PR Renne et al. (2010). Geochim. Cosmochim. Acta 75, 5097-5100.

Rosenfeld, A., Nathan, Y., Feibel, C.S., Schilman, B., Halicz, L., Goren-Inbar, N., SimanTov, R., 2004. Palaeoenvironment of the Acheulian Gesher Benot Ya'aqov Pleistocene lacustrine strata, Northern Israel - lithology, ostracod assemblages and ostracod shell geochemistry. J. African Earth Sci. 38, 169-181. doi:10.1016/j.jafrearsci.2003.10.008.

Sharon G., 2007. Acheulian large flake industries: Technology, chronology, and significance. BAR International Series, Oxford.

Sharon, G., Feibel, F., Alperson-Afil, N., Harlavan, Y., Feraud, G., Ashkenazi, S., Rabinovich, R., 2010. New evidence for the Northern Dead Sea Rift Acheulian. PaleoAnthropology 2010, 79-99. doi:10.4207/PA.2010.ART35.

Sharon, G., Alperson-Afil, N., Goren-Inbar, N., 2011. Cultural conservatism and variability in the Acheulian sequence of Gesher Benot Ya'aqov. J. Hum. Evol. 60, 387-397. doi:10.1016/j.jhevol.2009.11.012.

Snyder, S.W., Huber, B.T., 1996. Preparation techniques for use of foraminifera in the classroom [WWW Document]. URL http://www.ucmp.berkeley.edu/fosrec/Snyder\&Huber.html (accessed 3.3.10).

Spiro, B., Sharon, G., 2008. Preliminary report on the handling, sampling and storing of the geological core \#2-2006 from Gesher Benot Ya'aqov, Unpublished Project Report (IAA project 37782-0).

Spiro, B., Ashkenazi, S., Mienis, H.K., Melamed, Y., Feibel, C., Delgado, A., Starinsky, A., 2009. Climate variability in the Upper Jordan Valley around 0.78 Ma, inferences from time-series stable isotopes of Viviparidae, supported by mollusc and plant palaeoecology. Palaeogeogr. Palaeoclimatol. Palaeoecol. 282, 32-44. 
doi:10.1016/j.palaeo.2009.08.005.

Spiro, B., Ashkenazi, S., Starinsky, A., Katz, A., 2011. Strontium isotopes in Melanopsis sp. as indicators of variation in hydrology and climate in the Upper Jordan Valley during the Early-Middle Pleistocene, and wider implications. J. Hum. Evol. 60, 407-416.

Suc, J.-P., Popescu, S.-M., 2005. Pollen records and climatic cycles in the North Mediterranean region, in: Head, M.J., Gibbard, P.L. (Eds.), Early-Middle Pleistocene Transitions: The Land-Ocean Evidence. Geological Society of London, pp. 147-158. doi:10.1144/GSL.SP.2005.247.01.08.

Tzedakis, P.C., Hooghiemstra, H., Pälike, H., 2006. The last 1.35 million years at Tenaghi Philippon: Revised chronostratigraphy and long-term vegetation trends. Quat. Sci. Rev. $25,3416-3430$.

Van Zeist, W., Bottema, S., 1991. Late Quaternary vegetation of the Near East. Beihefte zum Tübinger Atlas des Vorderen Orients. Reihe A (Naturwissenschaften) Nr. 18. Dr. Ludwig Reichert Verlag, Wiesbaden.

Van Zeist, W., Bottema, S., 2009. A palynological study of the Acheulian site of Gesher Benot Ya'aqov, Israel. Veg. Hist. Archaeobot. 18, 105-121. doi:10.1007/s00334-0080167-5.

Van Zeist, W., Baruch, U., Bottema, S., 2009. Holocene palaeoecology of the Hula area, Northeastern Israel, in: Kaptijn, E., Petit, L.P. (Eds.), A Timeless Vale. Archaeological and Related Essays on the Jordan Valley in Honour of Gerrit van Der Kooij on the Occasion of His Sixty-Fifth Birthday. Leiden University Press, Leiden, pp. 29-64.

Wagner, C.W., 1957. Sur les ostracodes du Quaternaire récent des Pays-Bas et leur utilisation dans l'étude géologique des dépôts Holocènes. Mouton \& Co., 'S-Gravenhage. 
Zhou, L.P., Shackleton, N.J., 1999. Misleading positions of geomagnetic reversal boundaries in Eurasian loess and implications for correlation between continental and marine sedimentary sequences. Earth Planet. Sci. Lett. 168, 117-130.

Zohar, I., Goren, M., Goren-Inbar, N., 2014. Fish and ancient lakes in the Dead Sea Rift: The use of fish remains to reconstruct the ichthyofauna of Paleo-lake Hula. Palaeogeogr. Palaeoclimatol. Palaeoecol. 405, 28-41. doi:10.1016/j.palaeo.2014.04.006.

Zohary, M., 1982. Beihefte zum Tübinger Atlas des Vorderen Orients. Reihe A, No. 7: Vegetation of Israel and Adjacent Areas. Dr. Ludwig Reichert Verlag, Wiesbaden.

Zohary, M., Orshansky, G., 1947. The vegetation of the Huleh Plain. Palest. J. Bot. 4, 90-104.

\section{Figure Captions}

Fig. 1. Location map of the GBY site (after Horowitz, 1987) including position of the GBY excavation (after Goren-Inbar et al., 1992; Van Zeist and Bottema, 2009) and GBY\#2 core drilling points.

Fig. 2. Lithological composition of the GBY\#2 core (Spiro and Sharon, unpublished report, 2008), ${ }^{40} \mathrm{Ar} /{ }^{39} \mathrm{Ar}$ dating results, MIS subdivision and palaeomagnetic chrons.

Fig. 3. Photographs of the GBY\#2 core section showing: (A) underlying basalt between ca. 39.50 and $42.50 \mathrm{~m}$, (B) grey sandy marl containing mollusc shells and bioclasts at ca. $33.00 \mathrm{~m}$ and brown calcareous mud with dispersed mollusc shells at ca. $32.80 \mathrm{~m}$, (C) transition from grey mollusc-rich to brown sandy marl at ca. $27.00 \mathrm{~m}$, (D) above: transition from brown marl to low density peat in the lowermost row, changes from sandy sediment to light grey marl in the middle row and massive light grey calcareous marl in the topmost row; below: light grey 
calcareous marl with sparse and poorly preserved molluscs at ca. $22.20 \mathrm{~m}$, (E) light grey calcareous marl with mollusc shells between ca. 19.00 and $16.90 \mathrm{~m}$.

Fig. 4. Typical demagnetization diagrams. Full (open) symbols are vector projections of the Natural Remanent Magnetization (NRM) in the horizontal (vertical) plane. Line fits are indicated by green (red) lines on the horizontal (vertical) plane. (A) and (B) show alternating field demagnetizations of basaltic samples. (C), (D), (E) and (F) show thermal demagnetizations of sedimentary samples. Note the secondary low temperature component (LTC) well separated from the high temperature component (HTC) in (E) and overlapping the HTC in $(F)$ where the line fit was forced through the origin.

Fig. 5. Pollen diagram of the GBY\#2 section between 39.50 and $17.00 \mathrm{~m}$. The diagram is divided into five Local Pollen Assemblage Zones (LPAZ), based on the cluster analyses (CONISS) and conventional interpretation. For a detailed description of the lithological symbols see Fig. 2.

Fig. 6. Pollen of: (A) Cedrus at 37.40 m, (B) Salvinia massulae at 35.90 m, (C) Ephedra fragilis-type at $29.20 \mathrm{~m}$, (D) Azolla filiculoides massulae at $35.90 \mathrm{~m}$, (E-F) Ephedra fragilistype at $28.25 \mathrm{~m}$. Total magnification: $400 \mathrm{X}$.

Fig. 7. Plant macro-remains of the GBY\#2 core and their occurrence in relation to the Local Pollen Assemblage Zones (LPAZ).

Fig. 8. Plant macro-remains: (A) Azola cf. filiculoides macrospore in side view at $36.70 \mathrm{~m}$, (B) Azola cf. filiculoides microspore massulae in side view at $35.90 \mathrm{~m}$, (C) Salvinia cf. natans macrospore in side view at $28.80 \mathrm{~m}$, (D) Fumaria macrocarpa nutlet valve in dorsal view at $36.70 \mathrm{~m}$, (E) Ranunculus sceleratus seed in side view at $36.70 \mathrm{~m}$, (F) Stratiotes cf. intermedius spine in side view at $31.03 \mathrm{~m}$, (G) Butomus umbellatus seed in side view at 28.80 m, (H) Sagittaria cf. sagittifolia flattened seed in side view at $36.70 \mathrm{~m}$, (I) Typha cf. 
domingensis seed in side view at $28.80 \mathrm{~m}$, (J) Cyperus cf. articulatus nutlet in dorsal view at $31.30 \mathrm{~m},(\mathrm{~K})$ Cladium mariscus nutlet in side view at $33.20 \mathrm{~m}$, (L) Scirpus cf. lacustris nutlet in dorsal view at $36.70 \mathrm{~m}$.

Fig. 9. Mollusc remains and ostracod valves in the GBY\#2 core. The data are presented as presence-absence data (dots, mostly for mollusc identified to species level) and quantitative data (absolute count numbers as bars, mostly for taxa identified to genus level including less well preserved specimen not identified to species level).

Fig. 10. Correlation between the sequence of the GBY excavation (modified from Feibel, 2001, 2004, 2009 personal communication; Van Zeist and Bottema, 2009; Goren-Inbar et al., in press) in the southern part of the GBY site and the GBY\#2 core (modified from Spiro and Sharon, unpublished report, 2008) in the northern part of the archaeological site. The Matuyama-Brunhes Boundary (MBB) is the chronological reference for the correlation. The three other correlation lines are based on common palynological characteristics of both pollen profiles: C1 (first peak of Cedrus), C2 (second peak of Cedrus) and AA1 (first peak of Amaranthaceae and Artemisia). The last peak of Salvinia is indicated at $31.10 \mathrm{~m}$ in the excavation record and at $35.90 \mathrm{~m}$ in the GBY\#2 core. For further explanations see Fig. 5 and for a detailed description of the lithological symbols see Fig. 2.

\section{Table Captions}

Table 1. Palaeomagnetism measurements of the GBY\#2 core.

Table 2. Percentages of taxa that are not included in the GBY\#2 pollen diagram in relation to the Local Pollen Assemblage Zones (LPAZ). 
Table 3. Comparison between plant macro-remains and mean pollen percentages of the GBY\#2 core. 


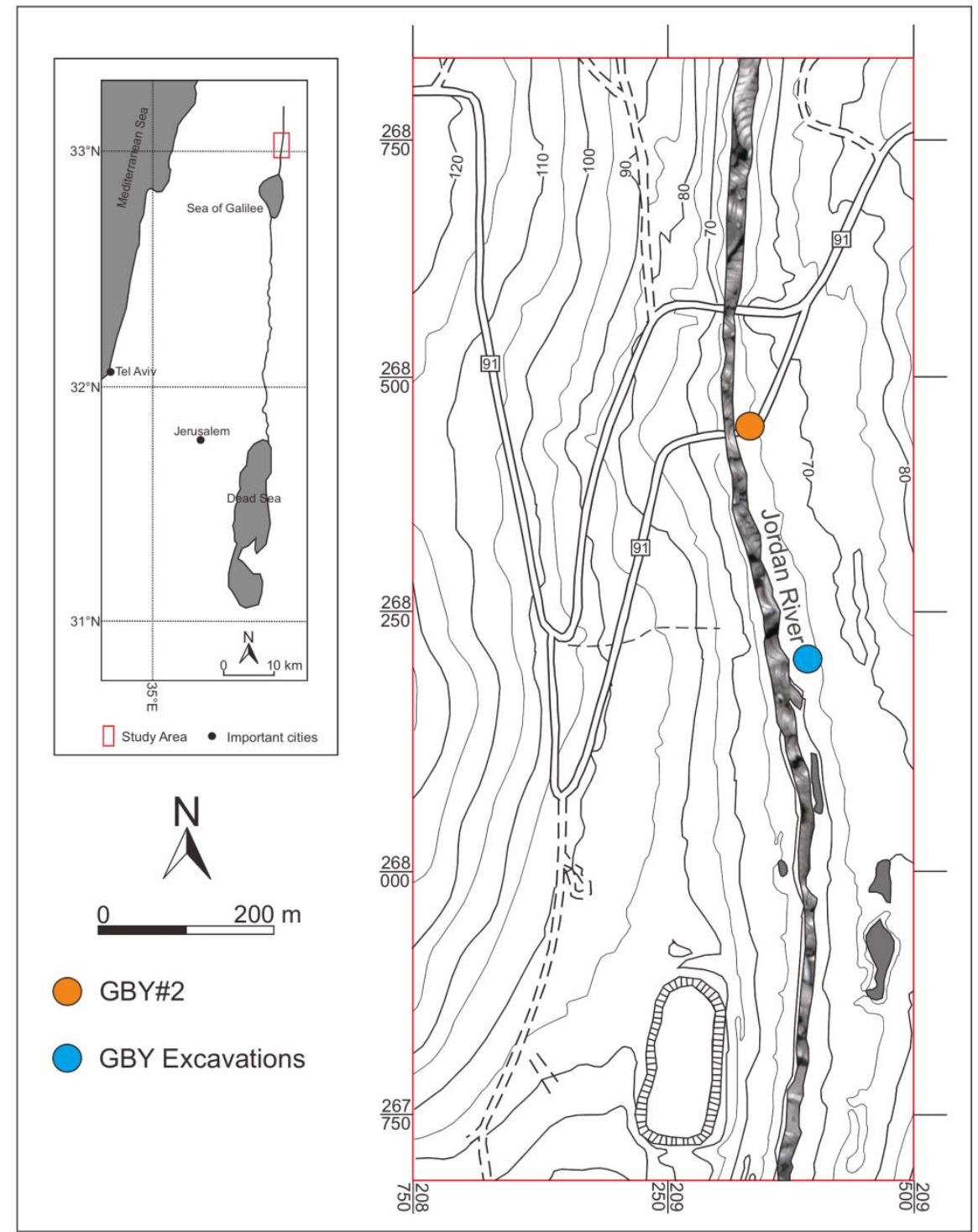

Fig. 1 


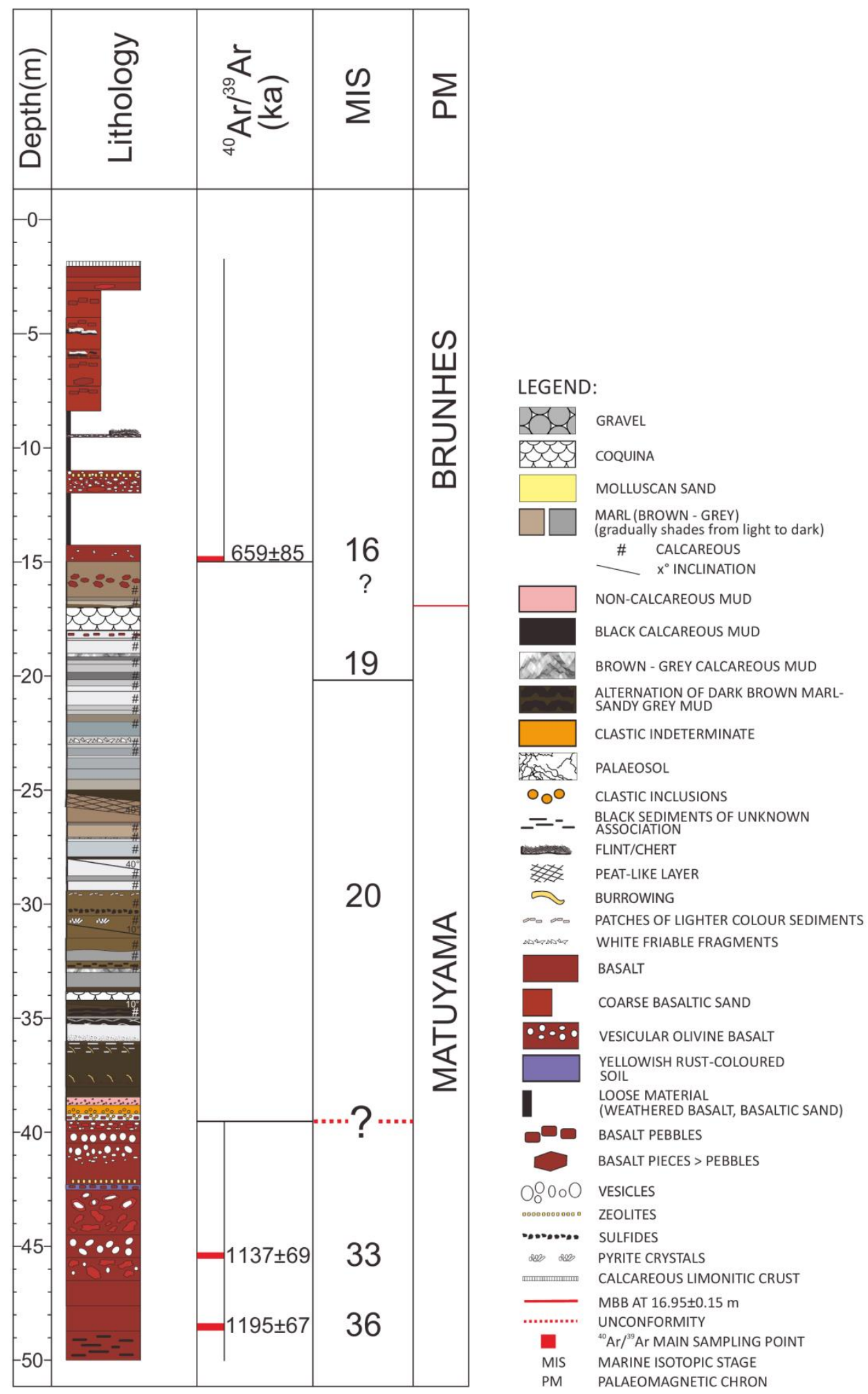

Lithological column is modified from Spiro and Sharon (unpublished report, 2008)

Fig. 2 


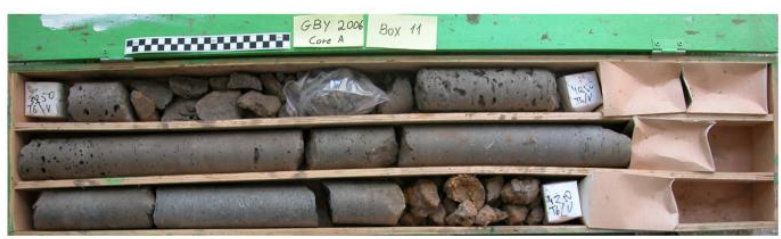

(A)
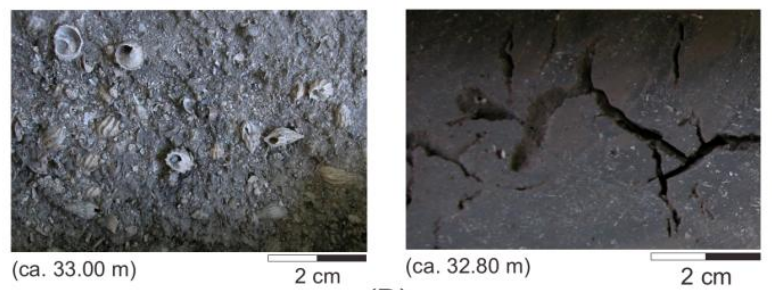

(B)
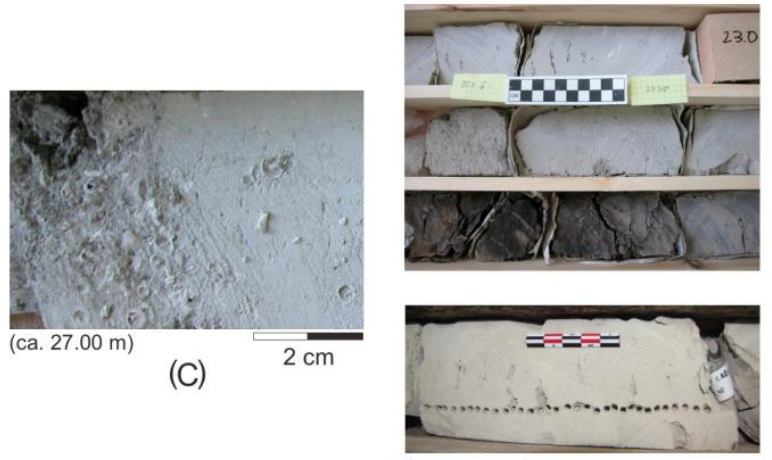

(ca. $22.20 \mathrm{~m}$ )

(D)

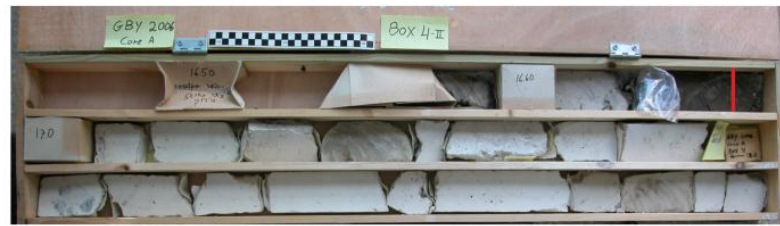

(E)

: Matuyama-Brunhes Boundary (MBB)

Fig. 3 
A. Level 46.50 (Basalt)

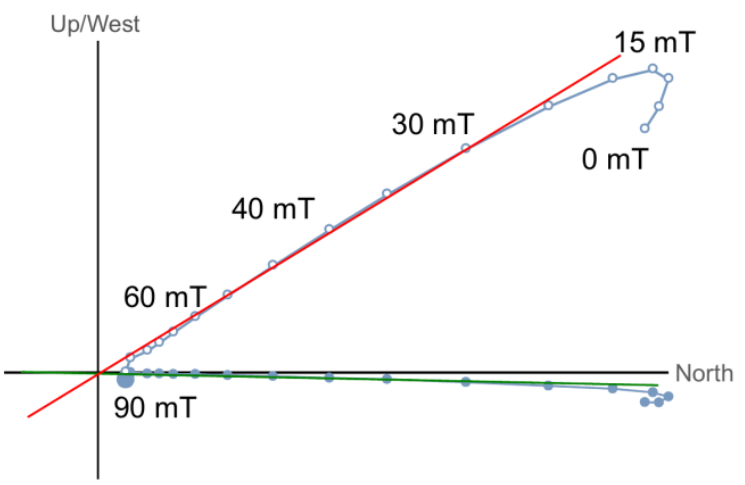

B. Level 14.90 (Basalt)

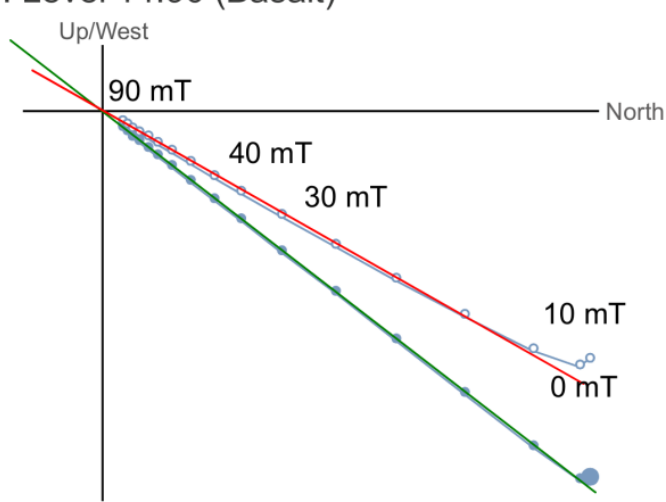

D. Level 16.80 (Sediment)

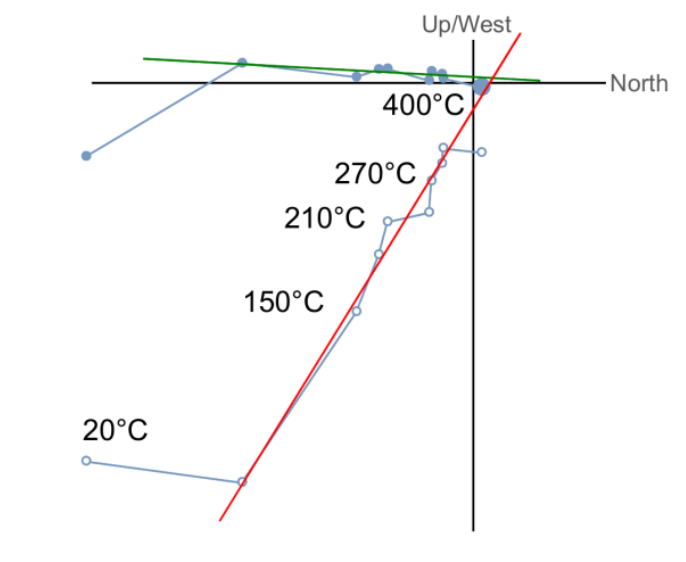

C. Level 23.20 (Sediment)

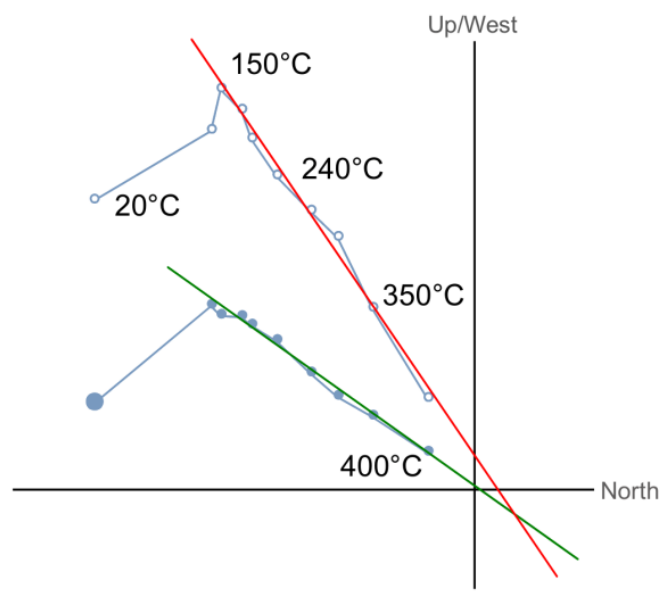

E. Level 18.35 (Sediment)

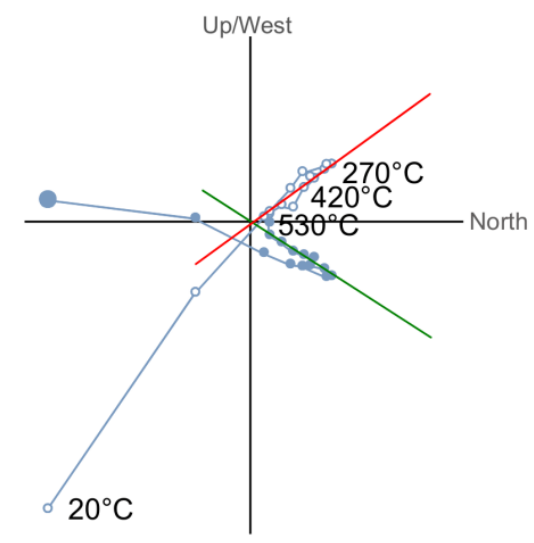

F. Level 17.10 (Sediment)

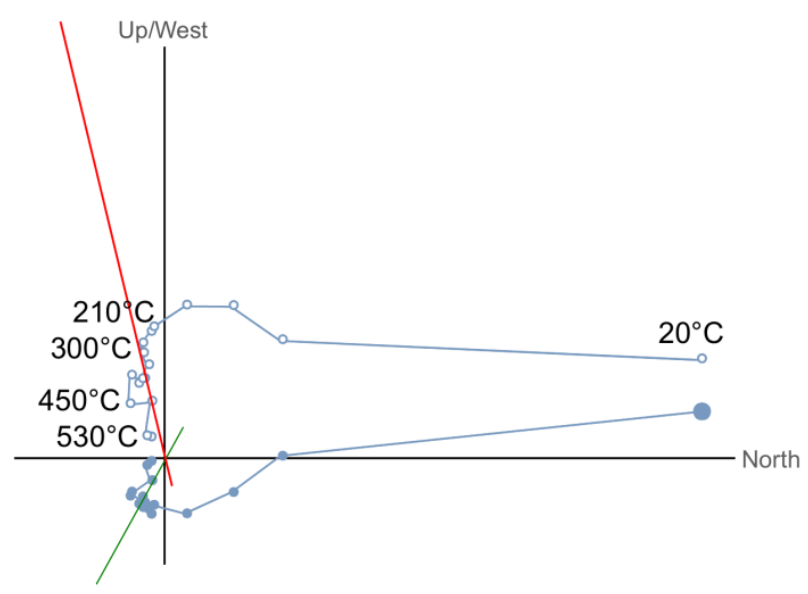

Fig. 4 
Gesher Benot Ya'aqov
Core GBY\#2

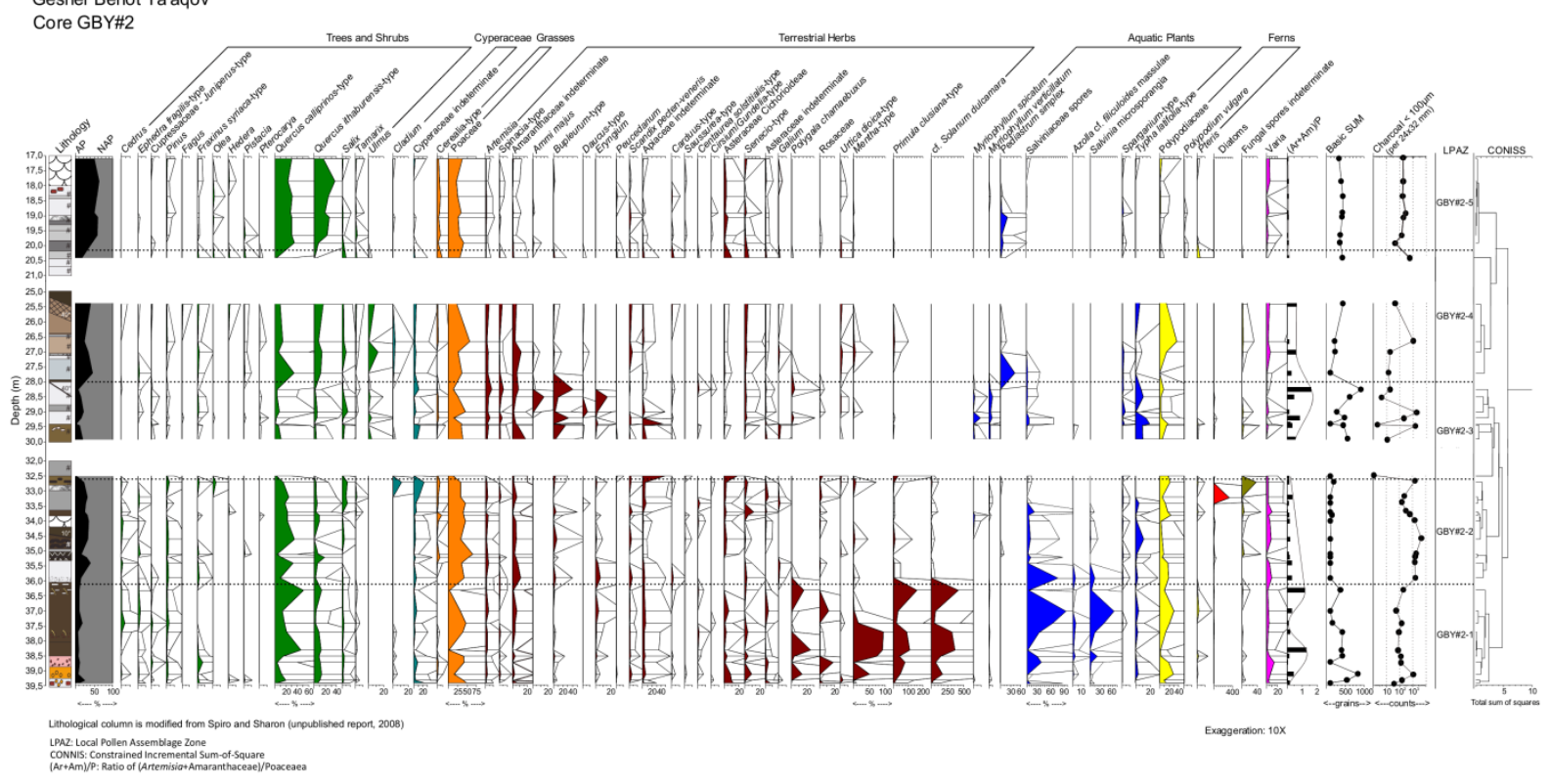

Fig. 5 

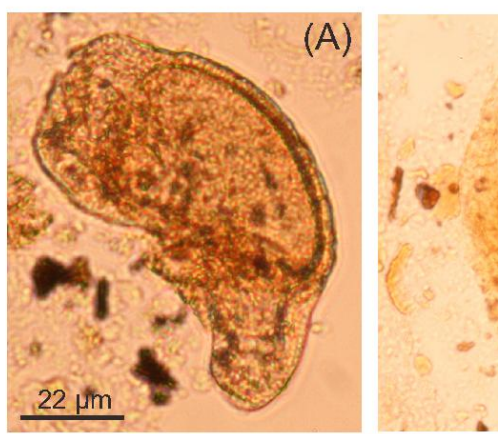

(B)
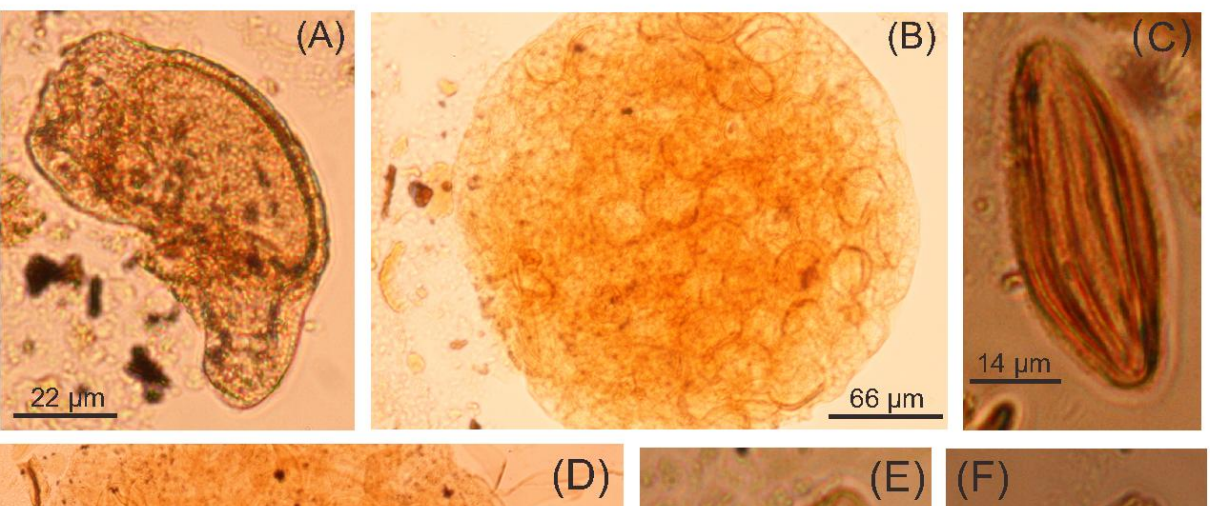

(D)
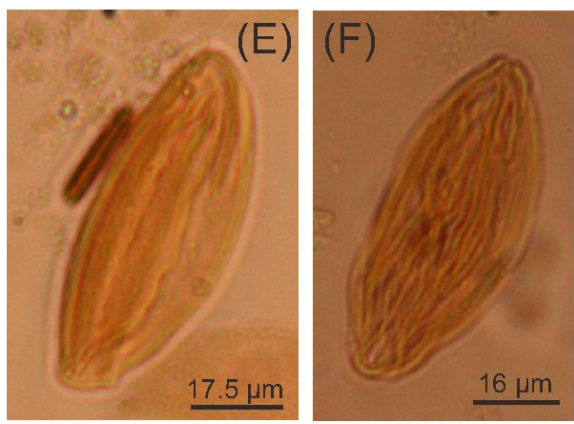

Fig. 6 
Plant macro-remains

GBY\#2

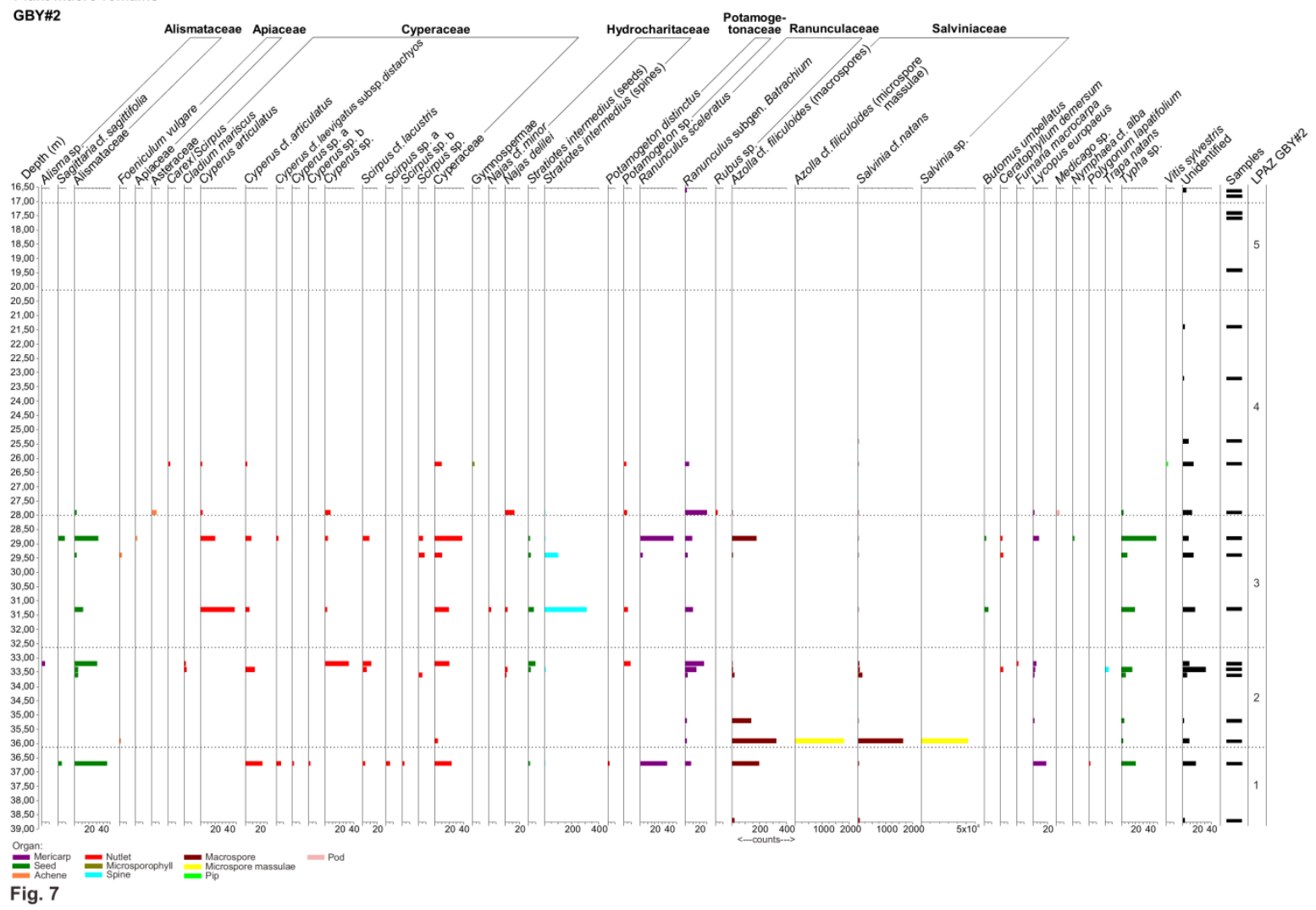

Fig. 7 

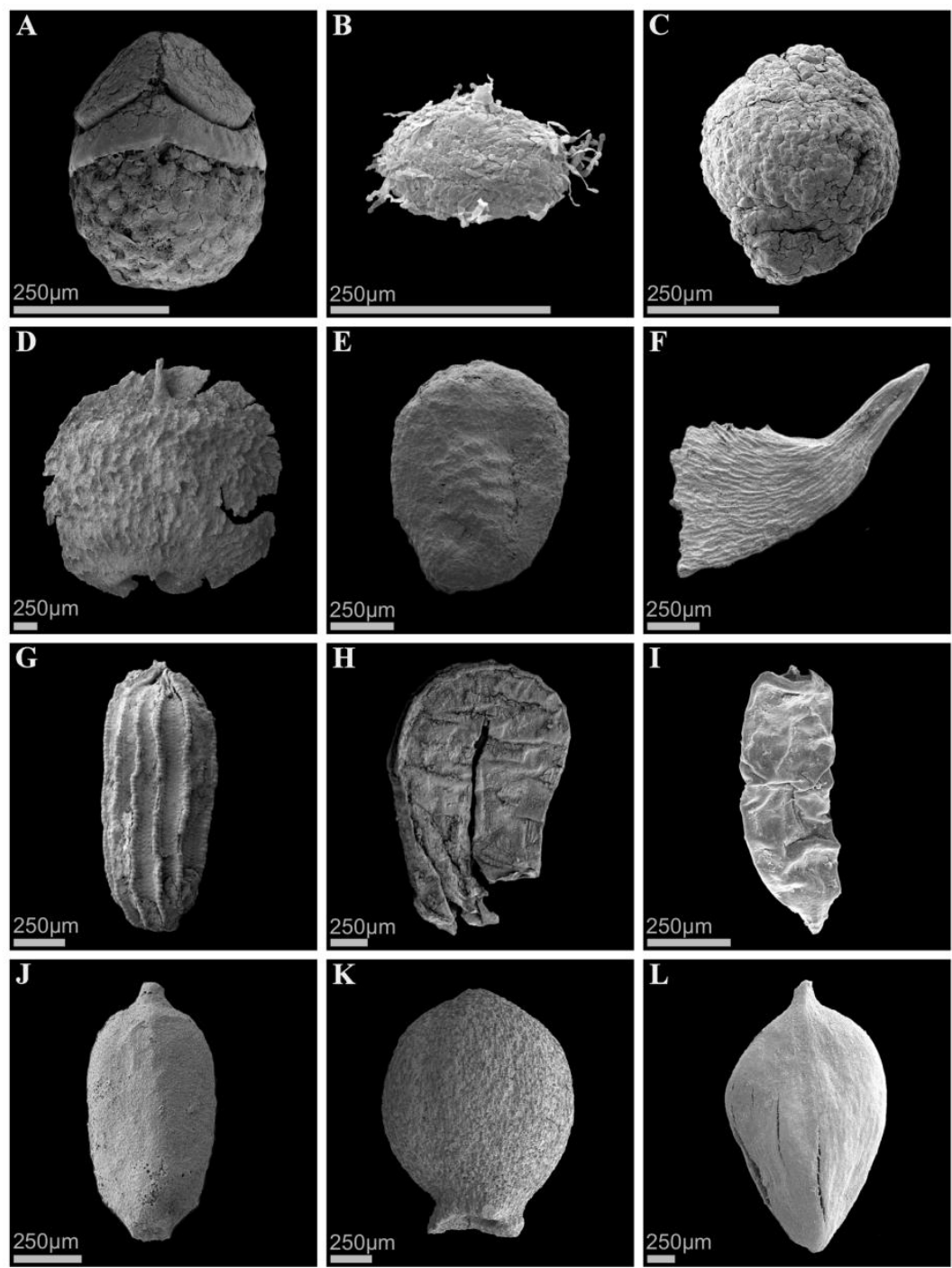

Fig. 8 


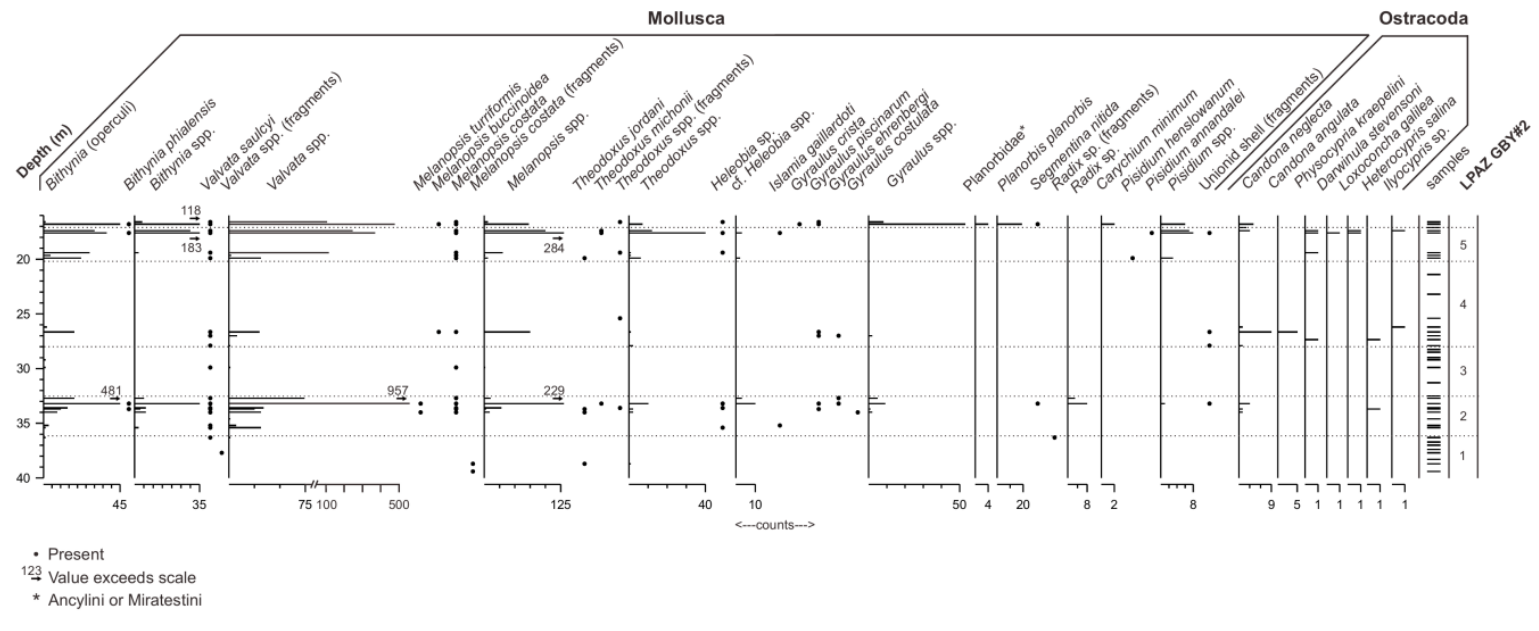

Fig. 9 


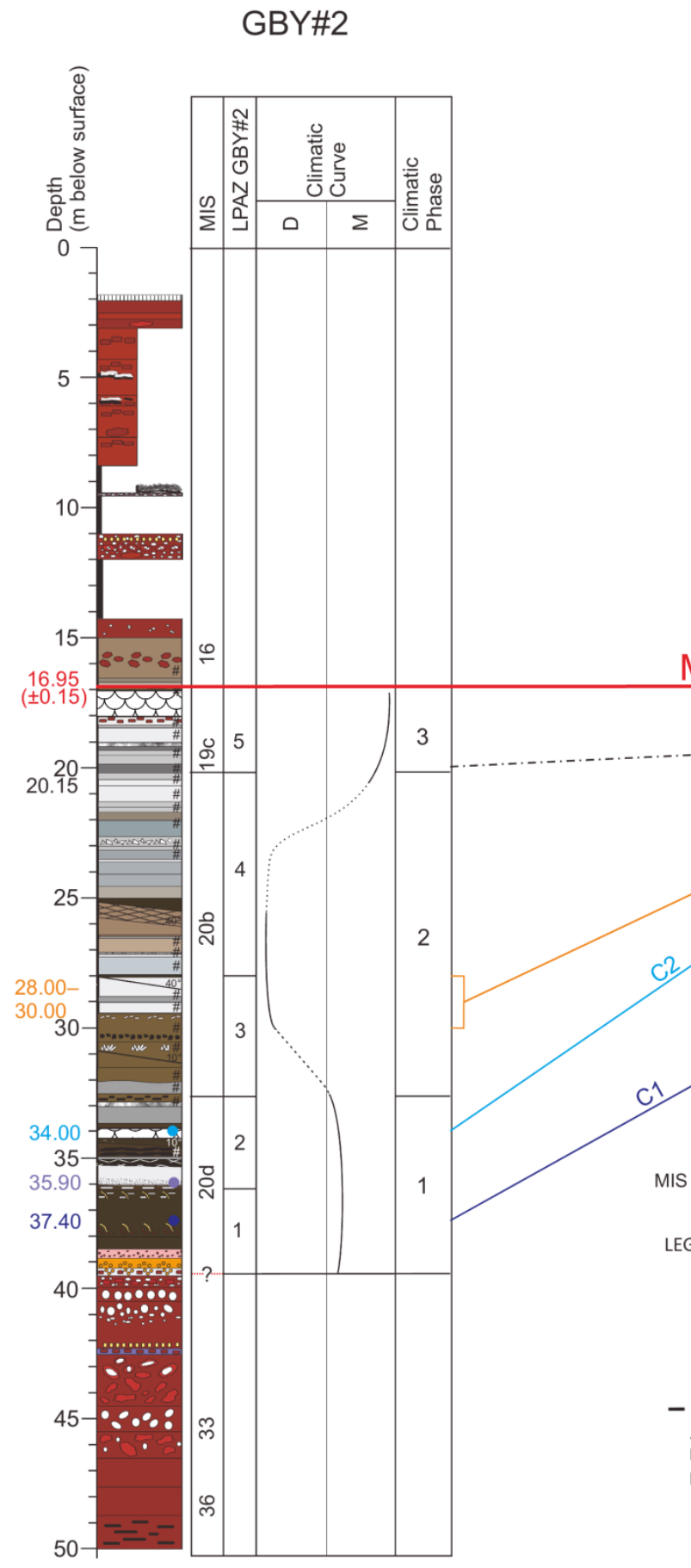

Lithological column is modified from Spiro and Sharon (unpublished report, 2008)

\section{GBY Excavations}

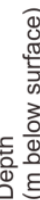

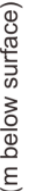

里这资
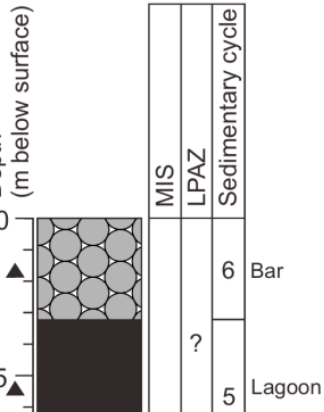

$\Delta$

Trench V-3,V-2

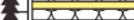

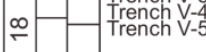

$10-$

A esese

Trench I-4
Trench I-5
Trench II-2

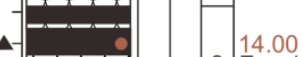

3 Trench II-5

Trench II-6

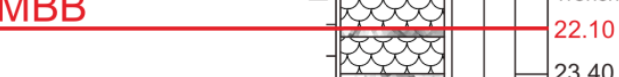

- $\div 2$ Trench II-12

3.40

Trench III-2
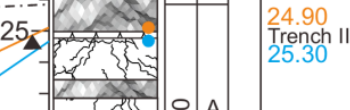

으 
Table 1

Palaeomagnetism measurements of the GBY\#2 core.

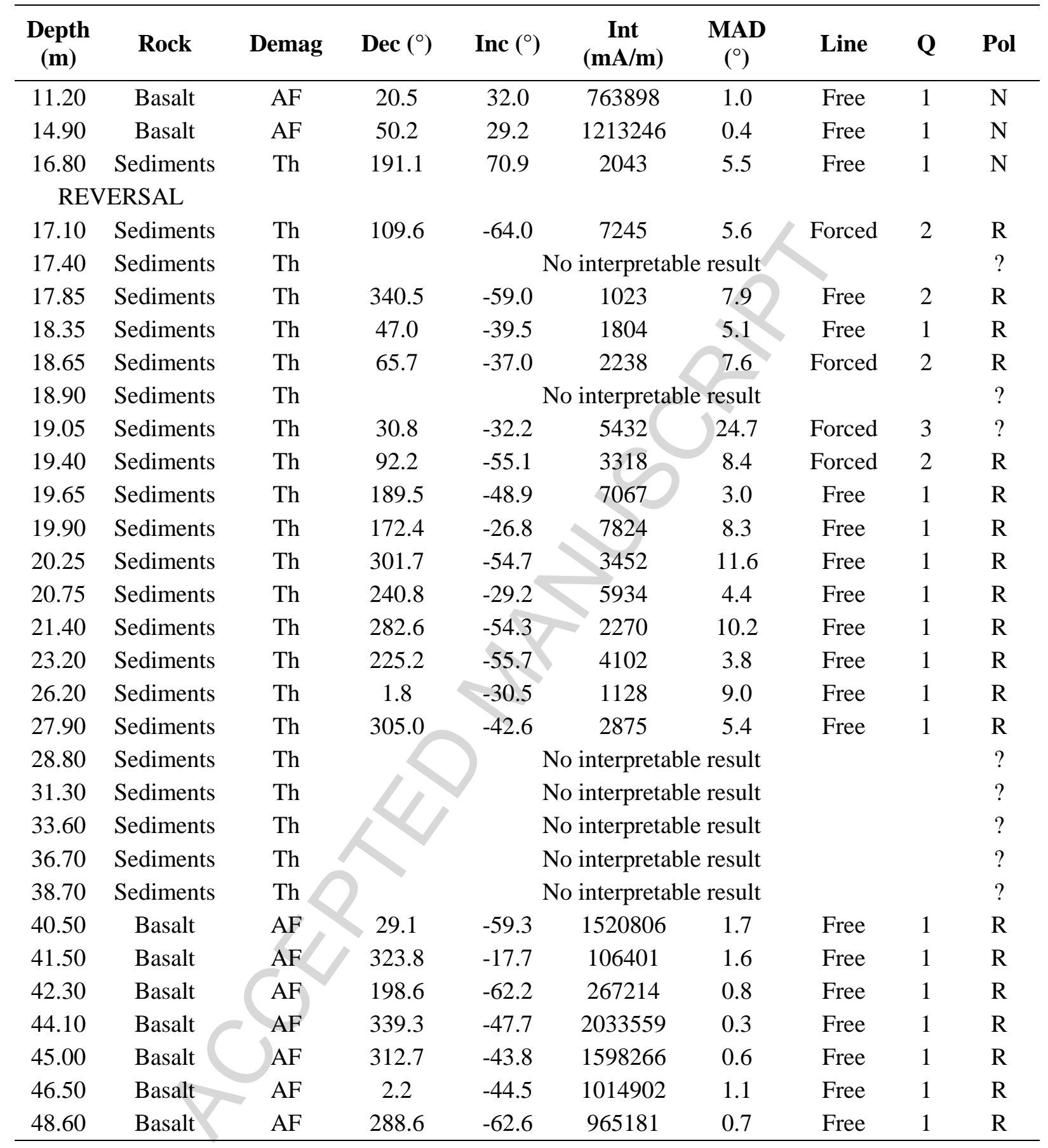

Depth in m below surface, Rock: rock type, Demag: demagnetization procedure applied (AF: alternating field, Th: thermal), Dec: declination of interpreted ChRM direction, Inc: inclination of interpreted ChRM direction, Int: intensity of ChRM direction, MAD: Maximum Angular Deviation on line fit performed to determine ChRM direction, Line: type of line fit applied (free or forced to the origin), Q: quality of direction and polarity determination (1: reliable direction and polarity, 2: reliable polarity but unreliable direction, 3: unreliable polarity and direction), Pol: Polarity determination (N: normal, R: reversed, ?: undetermined). 
Table 2

Percentages of taxa that are not included in the GBY\#2 pollen diagram in relation to the Local Pollen Assemblage Zones (LPAZ).

\begin{tabular}{|c|c|c|c|c|c|c|c|c|c|c|c|c|c|}
\hline \multirow[b]{2}{*}{$\begin{array}{l}\text { Depth } \\
\text { (m) }\end{array}$} & \multirow[b]{2}{*}{ LPAZ } & \multicolumn{12}{|c|}{ Pollen Taxon } \\
\hline & & $\begin{array}{c}\text { cf. Ziziphus } \\
\text { spina- } \\
\text { christi }\end{array}$ & $\begin{array}{l}\text { Pimpinella- } \\
\text { type }\end{array}$ & Anthemis & Brassicaceae & $\begin{array}{c}\text { Papaver } \\
\text { rhoeas-type }\end{array}$ & $\begin{array}{c}\text { Polygonum } \\
\text { aviculare }\end{array}$ & Ranunculaceae & Saxifragaceae & $\begin{array}{c}\text { Scabiosa } \\
\text { palestina- } \\
\text { type }\end{array}$ & $\begin{array}{l}\text { Ammi } \\
\text { majus }\end{array}$ & $\begin{array}{c}\text { Ferula- } \\
\text { type }\end{array}$ & $\begin{array}{l}\text { Pediastrum } \\
\quad \text { duplex }\end{array}$ \\
\hline 17.10 & \multirow{6}{*}{ GBY\#2-5 } & 0.6 & - & - & - & - & - & - & & - & - & - & - \\
\hline 17.85 & & - & - & - & 1.3 & - & - & - & & 0.8 & - & - & - \\
\hline 18.35 & & - & - & - & - & 0.7 & - & - & & 0.7 & - & 0.7 & - \\
\hline 18.90 & & - & - & - & - & - & - & 0.7 & - & 0.9 & 0.2 & - & - \\
\hline 19.05 & & - & - & - & - & - & - & & - & 0.2 & - & - & - \\
\hline 19.90 & & - & - & - & - & - & - & - & - & - & 1.1 & - & - \\
\hline 20.40 & \multirow{3}{*}{ GBY\#2-4 } & - & 1.6 & 1.4 & - & - & 0.2 & 0.5 & 0.7 & - & - & 0.5 & - \\
\hline 25.40 & & - & 1.1 & - & - & 0.2 & & 0.2 & 1.1 & - & - & - & - \\
\hline 27.00 & & - & - & - & - & - & - & - & - & - & 0.9 & 0.9 & - \\
\hline 28.25 & \multirow{7}{*}{ GBY\#2-3 } & - & - & - & - & & - & - & - & - & 0.3 & - & - \\
\hline 28.50 & & - & - & - & - & & 0.6 & - & - & - & 14.4 & - & - \\
\hline 29.00 & & 0.4 & - & - & - & & 0.7 & - & - & - & 1.1 & - & - \\
\hline 29.20 & & - & - & - & & - & 0.2 & - & - & - & & 12 & - \\
\hline 29.45 & & - & - & - & . & - & & - & 0.7 & - & - & - & - \\
\hline 29.90 & & - & 0.4 & - & - & - & - & - & - & - & - & - & - \\
\hline 32.50 & & - & - & - & - & 1 & - & - & - & - & - & - & - \\
\hline 34.00 & \multirow{2}{*}{ GBY\#2-2 } & - & - & - & - & 1 & - & - & - & - & - & - & - \\
\hline 35.10 & & - & - & - & 1 & - & - & - & - & - & - & - & - \\
\hline 38.30 & \multirow{4}{*}{ GBY\#2-1 } & - & 0.5 & - & - & - & - & - & - & - & - & - & - \\
\hline 39.10 & & - & 0.1 & - & - & - & - & - & - & 0.1 & - & - & - \\
\hline 39.30 & & - & - & 0.2 & - & - & - & - & - & - & - & - & 0.2 \\
\hline 39.40 & & - & - & - & - & - & - & - & - & - & - & - & 1 \\
\hline
\end{tabular}


Table 3

Comparison between plant macro-remains and mean pollen percentages of the GBY\#2 core.

\begin{tabular}{|c|c|c|c|}
\hline Taxa & $\begin{array}{l}\text { Plant macro- } \\
\text { remains }(\%)\end{array}$ & Taxa and pollen-types & $\begin{array}{c}\text { Mean } \\
\text { pollen/spores/non- } \\
\text { pollen } \\
\text { palynomorphs } \\
(\%)\end{array}$ \\
\hline Alismataceae & 3.62 & & \\
\hline Apiaceae & 0.05 & Apiaceae & 94.84 \\
\hline Asteraceae & 0.15 & Asteraceae & 31.40 \\
\hline Azolla cf. filiculoides (M) & 46.35 & Azolla cf. filic & 0.87 \\
\hline Butomus umbellatus & 0.18 & & \\
\hline Ceratophyllum demersum & 0.21 & & \\
\hline Cladium mariscus & 0.13 & Cladium & 1.37 \\
\hline Cyperaceae & 8.22 & Cyperaceae indeterminate & 21.28 \\
\hline Fumaria macrocarpa & 0.05 & & \\
\hline Gymnospermae & 0.05 & & \\
\hline Lycopus europaeus & 1.00 & & \\
\hline Medicago sp. & 0.10 & & \\
\hline Najas cf. minor & 0.08 & & \\
\hline Najas delilei & 0.54 & & \\
\hline Nymphaea cf. alba & 0.05 & & \\
\hline Polygonum lapatifolium & 0.05 & & \\
\hline Potamogeton distinctus & 0.05 & & \\
\hline Potamogeton sp. & 0.54 & & \\
\hline Ranunculaceae & 5.16 & Ranunculaceae & 0.09 \\
\hline Rubus sp. & 0.05 & & \\
\hline Salvinia (Ms) & 1333.74 & Salvinia (Ms) & 13.87 \\
\hline Stratiotes intermedius & 0.67 & & \\
\hline Trapa natans & 0.13 & & \\
\hline Typha sp. & 3.21 & Typha latifolia-type & 21.80 \\
\hline Vitis sylvestris & 0.00 & & \\
\hline
\end{tabular}

M: Massulae; Ms: Microsporangia 
Highlights:

- Change to warmer and moister climate marks the beginning of the Middle Pleistocene.

- Acheulian culture and human-induced fire were likely present since MIS 20.

- Shallower depositional environment was mainly caused by the prograding lake margin.

- Ideal niche for hominins occured during the end of the Early Pleistocene. 